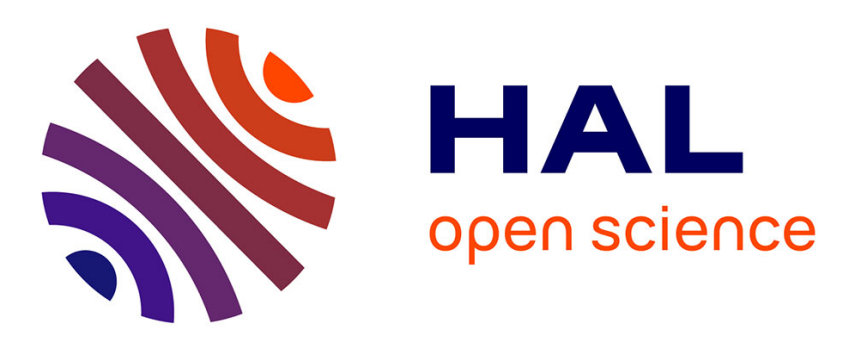

\title{
Spatial distribution of heterotrophic bacteria in the northeast Atlantic (POMME study area) during spring 2001
}

Melilotus Thyssen, Dominique Lefèvre, Guy Caniaux, Josephine Ras, Camila I. Fernandez, Michel Denis

\section{To cite this version:}

Melilotus Thyssen, Dominique Lefèvre, Guy Caniaux, Josephine Ras, Camila I. Fernandez, et al.. Spatial distribution of heterotrophic bacteria in the northeast Atlantic (POMME study area) during spring 2001. Journal of Geophysical Research, 2005, 110, pp.C07S16-16. 10.1029/2004JC002670 . hal-00092675

\section{HAL Id: hal-00092675 https://hal.science/hal-00092675}

Submitted on 18 Feb 2021

HAL is a multi-disciplinary open access archive for the deposit and dissemination of scientific research documents, whether they are published or not. The documents may come from teaching and research institutions in France or abroad, or from public or private research centers.
L'archive ouverte pluridisciplinaire HAL, est destinée au dépôt et à la diffusion de documents scientifiques de niveau recherche, publiés ou non, émanant des établissements d'enseignement et de recherche français ou étrangers, des laboratoires publics ou privés. 


\title{
Spatial distribution of heterotrophic bacteria in the northeast Atlantic (POMME study area) during spring 2001
}

\author{
Melilotus Thyssen, ${ }^{1}$ Dominique Lefèvre, ${ }^{1}$ Guy Caniaux, ${ }^{2}$ Josephine Ras, ${ }^{3}$ \\ Camila I. Fernández, ${ }^{4}$ and Michel Denis ${ }^{1}$ \\ Received 17 August 2004; revised 14 January 2005; accepted 18 May 2005; published 22 July 2005.
}

[1] Heterotrophic bacteria abundances, total chlorophyll $a(T \operatorname{chl} a)$, and nitrate concentrations were determined during the spring cruise (23 March-13 April 2001) of the Programme Océan Multidisciplinaire Méso Echelle (POMME) in the northeastern Atlantic between $39.0^{\circ}-44.5^{\circ} \mathrm{N}$ and $16.6^{\circ}-20.6^{\circ} \mathrm{W}$. Sampling covered a grid of 81 stations regularly spaced. Three bacteria subpopulations (HNA1, HNA2, and LNA) were resolved by flow cytometry on the basis of their nucleic acid content, after staining with SYBR Green II (molecular probes), and by their scatter properties. The bacterial distribution was investigated down to $600 \mathrm{~m}$ depth. HNA2 were essentially observed in the upper $200 \mathrm{~m}$ and were not present at all stations. HNA1 dominated in the surface layer and were positively linked to $T \mathrm{chl} a$. This relationship exhibited some heterogeneity due to the latitudinal evolution of the phytoplankton bloom and the seasonal thermocline formation already occurring in the south. In contrast, LNA dominated the bacterial subgroups below $100 \mathrm{~m}$ depth, and their distribution bore the fingerprint of the geostrophic current field and the mesoscale features identified in the study area, i.e., cyclonic and anticyclonic eddies and frontal structures.

Citation: Thyssen, M., D. Lefèvre, G. Caniaux, J. Ras, C. I. Fernández, and M. Denis (2005), Spatial distribution of heterotrophic bacteria in the northeast Atlantic (POMME study area) during spring 2001, J. Geophys. Res., 110, C07S16, doi:10.1029/2004JC002670.

\section{Introduction}

[2] Bacterial community in the open ocean plays an important role in the carbon cycle by partially controlling the flux of $\mathrm{CO}_{2}$ and its sequestration in deep waters through the demineralization of organic matter in the upper layer [Cho and Azam, 1988]. Indeed, bacteria have a great ability to respond to increases of primary production rates by raising their bacterial growth efficiency [Gonzalès et al., 2003]. As a consequence, on a small scale, bacterial distribution and community structure are tightly linked to dissolved organic matter availability [Long and Azam, 2001]. The bacteria abundance is controlled by grazing pressure [Jürgens et al., 2000], temperature, pressure, hydrodynamism and bottom-up control [Dufour and Torreton, 1996; Billen et al., 1990]. There is competition with phytoplankton for ammonia and phosphate in oligotrophic waters [Wheeler and Kirchman, 1998; Kirchman and Wheeler, 1998].

\footnotetext{
${ }^{1}$ Centre d'Océanologie de Marseille, Laboratoire de Microbiologie, Géochimie et Ecologie Marines, Centre National de la Recherche Scientifique, UMR 6117, Université de la Méditerranée, Marseille, France. ${ }^{2}$ Centre National de Recherche Météorologique, Toulouse, France.

${ }^{3}$ Laboratoire d'Océanographie de Villefranche, Villefranche-sur-Mer, France.

${ }^{4}$ Centre d'Océanologie de Marseille, Laboratoire d'Océanographie et de Biogéochimie, Marseille, France.
}

Copyright 2005 by the American Geophysical Union. 0148-0227/05/2004JC002670
[3] On a larger scale, heterotrophic bacteria biomass is the most constant parameter observed in the oceans with respect to the other heterotrophic and autotrophic groups [ $\mathrm{Li}$ and Harrison, 2001], even if their abundance may vary with temperature [Hoppe et al., 2002]. Bacteria community may represent the main stock of carbon and nitrogen in the oceans [Fuhrman et al., 1989], and can exceed the autotrophic biomass [Fuhrman, 1992]. Two main subgroups were usually discriminated through flow cytometry analysis: high nucleic acid (HNA) and low nucleic acid (LNA) cells. Gasol et al. [1999] and Lebaron et al. [2001] observed that these two groups correspond to more and less active cells respectively. However, the situation might not be so clearcut since, in different studies, some LNA were found viable [Grégori et al., 2003] and able to divide twice as fast as HNA [Zubkov et al., 2001]. Jochem et al. [2004] showed that LNA could be considered as an integral part of the microbial food web, so that their contribution to production and demineralization may be underestimated. Zubkov et al. [2001] observed as well a difference in the vertical distribution of these two bacterial subgroups, with a dominance of LNA below the mixed layer depth.

[4] Thus the determination of the bacteria community structure through DNA content, abundance, spatial distribution is of importance when addressing their ecological and biological implication that can be assessed by flow cytometry [Li et al., 1995; Gasol et al., 1999; Troussellier et al., 1999; Lebaron et al., 2001; Zubkov et al., 2001; Grégori et al., 2003]. 
(B)

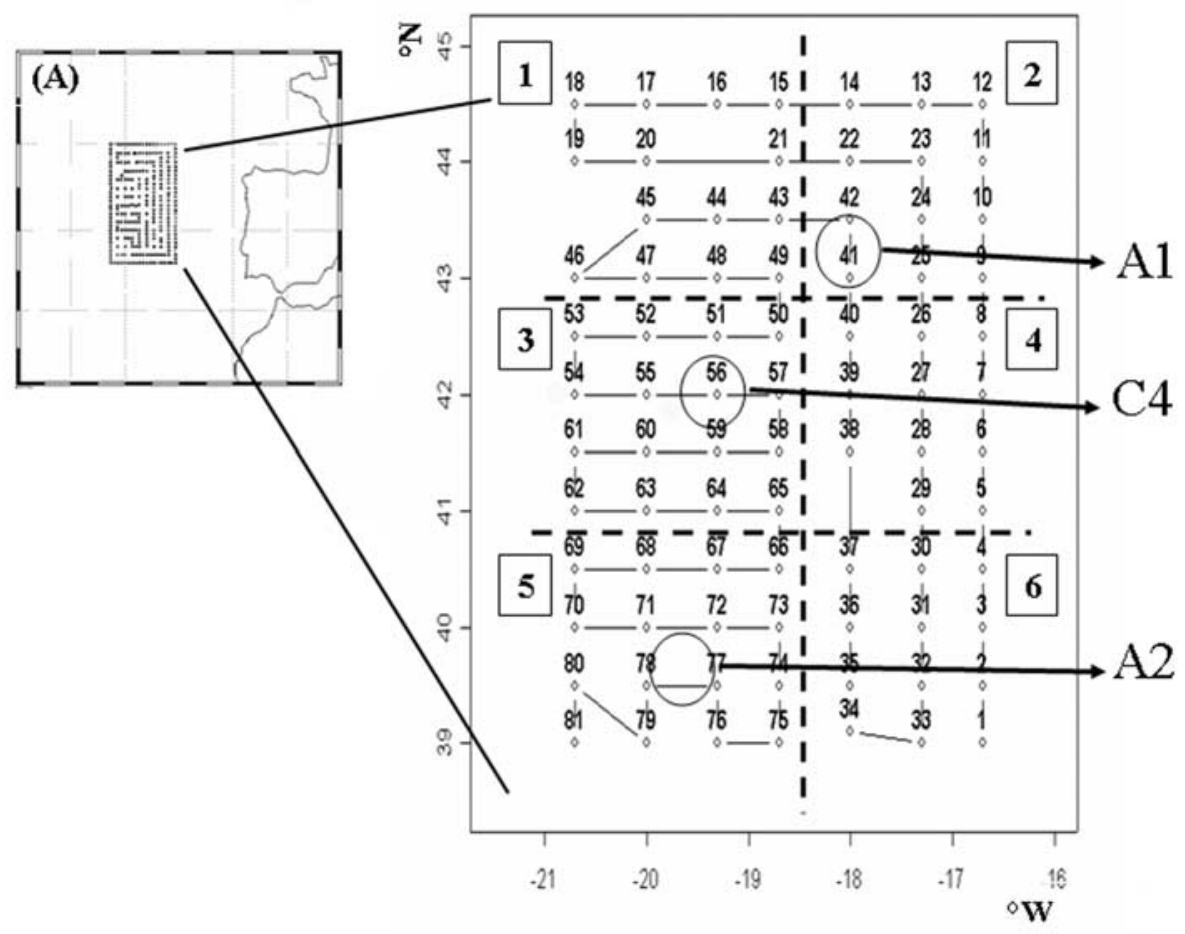

Figure 1. (a) Location of the study area in the northeastern Atlantic Ocean. (b) Stations occupied during leg 1 of the 2001 Programme Océan Multidisciplinaire Méso Echelle (POMME) spring cruise (23 March-13 April), numbered in the order of their sampling. Labeled mesoscale features: A1 and A2, anticyclonic gyre; $\mathrm{C} 4$, cyclonic gyre. The study area was subdivided into six regions to minimize the nonsynopticity of the sampling when considering the relationships between bacteria, Tchla, and nitrate.

[5] The winter mixed layer depth defined as the permanent thermocline, is of crucial importance in areas where nutrients are depleted, the spring bloom intensity being conditioned by the subsequent surface layer enrichment together with the seasonal thermocline formation [Dutkiewicz et al., 2001; Siegel et al., 2002]. By advecting or convecting water masses [Mc Gillicuddy and Robinson, 1997; Martin and Richards, 2001], mesoscale features contribute to changes in the ocean biogeochemistry and in particular to the nutrient enrichment of the upper layer [Jenkins, 1988]. One of the biological responses to these features results in a patchiness distribution of the phytoplanktonic community [Martin, 2003 ] that is well observed when using remote sensing. The bacterial distribution is less documented due to the lack of sampling at a mesoscale level and the use of flow cytometry is critical to achieve it due to its fast rate analysis and easy use.

[6] Oceanic circulation is likely to have a lasting impact on bacteria rather than phytoplankton whose growth will be hampered by the turbulence and the subsequent reduction of exposure to light [Martin et al., 2001]. One of the objectives of the Programme Océan Multidisciplinaire Méso Echelle (POMME) spring cruise was to investigate the occurrence of the spring bloom in connection with the mesoscale hydrodynamic features and the subducted waters. Eddies present in the study area were supposed to make the subduction heterogeneous or enhancing it, and affect the spring bloom.
[7] In the present paper, we report on the spatial distribution of the bacterial community in the POMME study area, taking into account its hydrodynamic features. Data were analyzed to establish to which extent the bacterial distribution was mainly explained by the potential nutritional pool (Tchla and nitrate) or by the physical constraints such as geostrophic currents and mesoscale features. Results provide evidence of the occurrence of both situations in the study area during spring 2001.

\section{Materials and Methods}

\subsection{Study Area and Sample Collection}

[8] In spring 2001, from 23 March to 13 April, the POMME spring cruise on $\mathrm{R} / \mathrm{V}$ L'Atalante, a contribution to the French POMME program, sampled a part of the POMME study area located in the northeastern Atlantic Ocean (Figure 1a), between $39.0^{\circ}-44.5^{\circ} \mathrm{N}$ and $16.6^{\circ}-$ $20.6^{\circ} \mathrm{W}$. Eighty one stations were occupied along seven north-south transects regularly spaced $\left(0.7^{\circ}\right.$ of longitude (Figure 1b)). Each transect was defined by 12 stations spaced by $0.7^{\circ}$ of latitude, station 1 being located at $16.6^{\circ} \mathrm{E}, 39.0^{\circ} \mathrm{N}$. The sequence of the visited stations was such that the closest stations of a given one were occupied in a time interval of less than 5 days.

[9] Seawater samples were collected using a conductivitytemperature-depth (CTD) probe (Seabird ${ }^{\circledR}$ SBE 9) equipped with an oxygen sensor (Seabird SBE 13) and a fluorometer 
$\left(\right.$ Seatech $\left.{ }^{\circledR}\right)$ and mounted on a rosette of 21 Niskin bottles $\left(12 \mathrm{dm}^{3}\right)$. For bacteria analysis by flow cytometry, seawater was sampled at 14 depths between 0 and $600 \mathrm{~m}$.

\subsection{Flow Cytometry}

[10] Prefiltered (100 $\mu \mathrm{m}$ mesh size net) seawater samples were preserved with $2 \%$ paraformaldehyde [Troussellier et al., 1999] frozen onboard and stored in liquid nitrogen. Back in the laboratory, samples were thawed at room temperature and analyzed with a flow cytometer (Cytoron Absolute, ORTHO Diagnostic Systems) equipped with an air-cooled $488 \mathrm{~nm}$ argon laser. The sample and sheath rates were 1 and $100 \mathrm{~mm}^{3} \mathrm{~s}^{-1}$ respectively.

[11] For each cell, five optical parameters were recorded: two diffraction parameters, namely forward angle scatter (related to the particle size) and right angle scatter (related to cell structure), and three fluorescence parameters measuring emissions in the red $(\sim 620 \mathrm{~nm})$, orange $(565-592 \mathrm{~nm})$ and green $(515-530 \mathrm{~nm})$ wavelength ranges. Data were collected and stored in list mode with the IMMUNOCOUNT software (ORTHO Diagnostic Systems). This software provides directly the cell concentration (cells $\mathrm{mm}^{-3}$ ) of the resolved subpopulations. Cluster analyses were run with WINLIST software (VERITY ${ }^{\circledR}$ Software House).

[12] Bacteria that required staining of their nucleic acids to become fluorescent upon the $488 \mathrm{~nm}$ laser excitation were labeled heterotrophic bacteria even though some of them might be photoheterotrophic [Kolber et al., 2000, 2001]. This labeling was of common use until the recent discovery of this new component of the bacterial community and keeping its use makes easier comparisons with previous works. For the staining of the bacteria nucleic acids, $1 \mathrm{~cm}^{3}$ seawater subsamples were supplemented with $10 \mathrm{~mm}^{3}$ SybrGreen II (from the Molecular Probes ${ }^{\circledR}$ solution diluted 1/5000 in final solution) and incubated $15 \mathrm{~min}$ in the dark before analysis. Counting reproducibility was better than $3.7 \%(\mathrm{CV}, n=23)$ over a range of concentration extending one order of magnitude [Grégori et al., 2001]. Flow cytometry does not give access to species identification (except in the case of in situ hybridization) and the subpopulations resolved by flow cytometry may be composed of several species [Zubkov et al., 2001]. There is no reference to species in our work and the observed changes in the analyzed subpopulations properties may either occur within the same species or derive from changes in species composition or both.

\subsection{Total Chlorophyll $a$}

[13] A volume of $2.7 \mathrm{dm}^{3}$ of seawater was filtered on GF/ $\mathrm{F}$ filters that where stored in liquid nitrogen for laboratory analysis. Total chlorophyll $a(T \operatorname{chl} a=$ chlorophyll $a+$ divynil chlorophyll $a+$ chlorophyllid $a$ ) was extracted with $3 \mathrm{~cm}^{3}$ methanol and analyzed by high performance liquid chromatography (Agilent 1100 HPLC) which was configured to a reverse phase C8 Hypersil MOS column (dimensions: $3 \times 100 \mathrm{~mm}, 3 \mu \mathrm{m}$ pore size) and Thermoquest AS3000 autosampler [see Claustre et al., 2004]. The detection limit was $0.001 \mathrm{mg} \mathrm{m}^{-3}$.

\subsection{Nitrate}

[14] Samples for nitrate $\left(\mathrm{NO}_{3}\right)$ analysis were collected into $20 \mathrm{~cm}^{3}$ polyethylene bottles that were prerinsed with
$10 \%$ hydrochloric acid. Samples were analyzed immediately using a Technicon ${ }^{\circledR}$ Auto Analyzer according to Tréguer and Le Corre [1975]. Nitrate detection limit was $0.050 \mu \mathrm{M}$ with an error estimated at $0.040 \mu \mathrm{M}$.

\subsection{Mixed and Euphotic Layer Depths and Mesoscale Features}

[15] The euphotic layer depth (ELD) was calculated from Tchla profiles using the model developed by Morel and Maritorena [2001] where Tchla content in the water column was obtained by integrating chl $a$ over depth. ELD values were further refined through an iterative process described by Morel and Berthon [1989]. The mixed layer depth (MLD) was derived from the depth where the vertical density difference with surface exceeded $0.02 \mathrm{~kg} \mathrm{~m}^{-3}$.

[16] In order to study the impact of physical mesoscale features on bacteria spatial distribution, geostrophic current fields were used. CTD, expendable bathythermograph (XBT), and expandable conductivity-temperature-depth (XCTD) data sets were used in order to produce highresolution temperature and salinity analyses which were interpolated vertically onto 65 vertical levels $(5 \mathrm{~m}$ near the surface and $300 \mathrm{~m}$ at depth) and then objectively analyzed onto a $5 \mathrm{~km}$ horizontal grid for all vertical levels. The first guess of the analyses was derived from the temperature and salinity [Levitus and Boyer, 1994; Levitus et al., 1994] climatology. At each point of the grid, the climatology was corrected, following the procedure of de Mey and Ménard [1989]. From these analyses, currents were computed at each level through the geostrophic approximation by using a level of no motion located near 1400 dbar as was done by Stramma [1984]. A detailed description of this procedure is described in a former article in the frame of the POMME experiment [Fernández et al., 2005a].

\subsection{Multiple Correspondence Analysis}

[17] The variability of the bacteria subpopulation distribution over the study area was investigated using a multi correspondence analysis (MCA) [Benzécri, 1980; Greenacre, 1984] under R package [Ihaka and Gentleman, 1996] (http:// www.r-project.org). The MCA is a weighted principal component analysis of a contingency table based on the chi-square distance between categories of each variable. Thus it summarizes relationships between quantitative data that are qualitatively transformed through categorization, and displays them graphically in a space that has as few dimension as possible.

\section{Results}

\subsection{Hydrodynamical Situation}

[18] A full description of physical features and hydrological properties of the investigated area is provided in the present issue [Assenbaum and Reverdin, 2005; Le Cann et al., 2005; Fernández et al., 2005a].

[19] Three main eddies (Figure 1b) were identified: a cold core cyclonic eddy $\left(\mathrm{C} 4,42^{\circ} \mathrm{N}-19.5^{\circ} \mathrm{W}\right)$, a cold core anticyclonic eddy $\left(\mathrm{A} 1,43^{\circ} \mathrm{N}-18^{\circ} \mathrm{W}\right)$ and a warm core anticyclonic eddy $\left(\mathrm{A} 2,40^{\circ} \mathrm{N}-19.5^{\circ} \mathrm{W}\right.$ [see also Fernández et al., 2005a]). Two frontal systems set the transition between the northern and southern areas [Fernández et al., 2005a; Mémery et al., 2005]. One was located between A2 and 

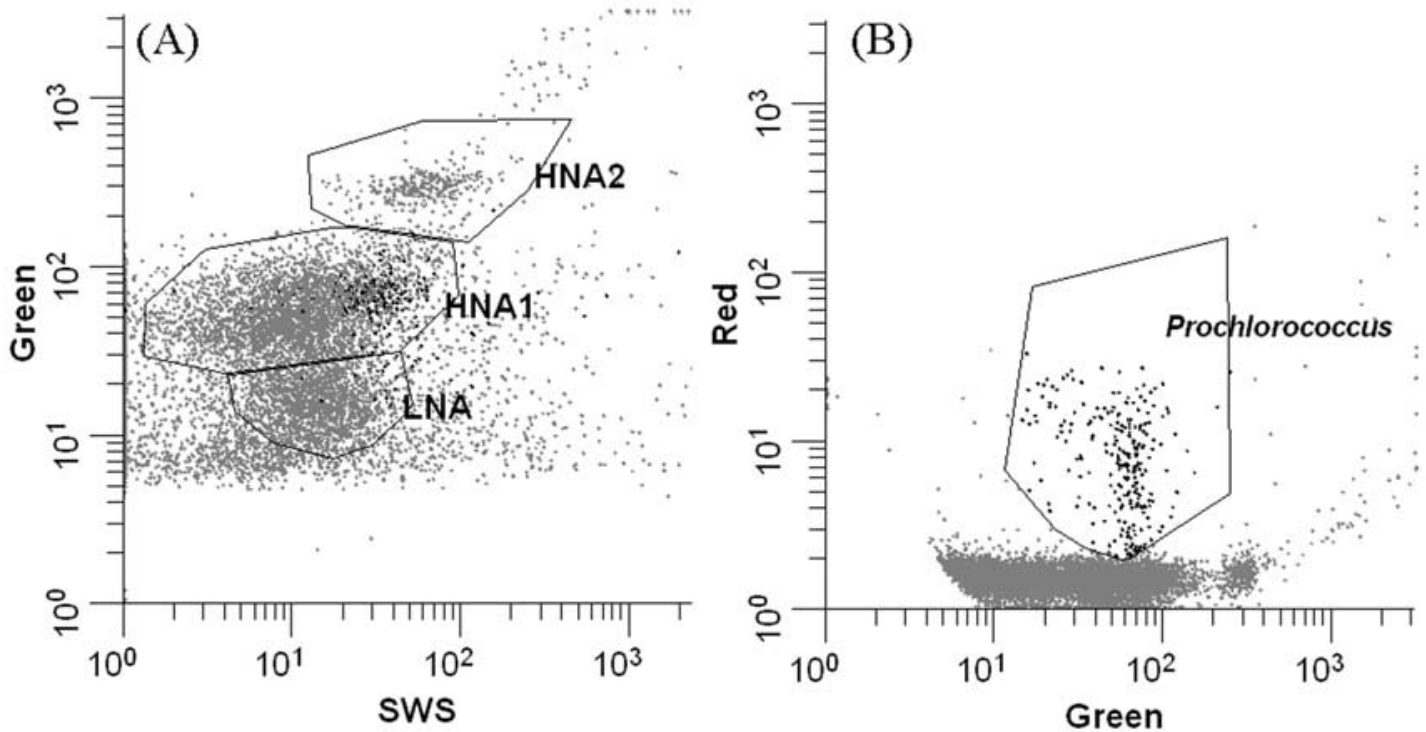

Figure 2. (a) Green fluorescence (arbitrary units) versus side scatter (SWS, arbitrary units) cytogram. (b) Red versus green fluorescence cytogram. Prochlorococcus cells were subtracted from bacterial counts in Figure 2a by using their red fluorescence shown in Figure $2 b$.

$\mathrm{C} 4$ on the western side of the study area whereas the other was positioned at about $41^{\circ} \mathrm{N}$ on the eastern side and characterized by the deepening of the $26.9 \mathrm{~kg} \mathrm{~m}^{-3}$ isopycnal. The area north of this front exhibited colder waters (sea surface temperature of about $13.5^{\circ} \mathrm{C}$ ), high nitrate concentrations [Fernández et al., 2005a], and a deep mixed layer (78 $\pm 54 \mathrm{~m}$ mean). In contrast, the area south of this front had a sea surface temperature reaching $16^{\circ} \mathrm{C}$, nitrate concentrations at the limit of detection, and stratified waters with a shallow mixed layer ( $31 \pm 24$ m mean).

\subsection{Bacterial Subpopulations}

[20] The flow cytometry analyses distinguished three bacterial subpopulations on the basis of their nucleic acid staining and side scatter signals. These subpopulations were labeled LNA, HNA1 and HNA2 from their low and high nucleic acid contents respectively (Figure 2a). HNA1 and LNA reached maximal abundance values of 8.5 and $10.6 \times$ $10^{5}$ cells $\mathrm{cm}^{-3}$ in surface waters respectively. HNA2 bacteria were not present at every station and were essentially observed in surface waters. They exhibited higher green fluorescence and higher side scatter signals than HNA1 bacteria. HNA2 reached mean abundance values of $3.810^{4} \pm 4.1 \times 10^{4}$ cells cm ${ }^{-3}$ with a maximal value of $3 \times$ $10^{5}$ cells cm ${ }^{-3}$.

[21] The overlapping of stained Prochlorococcus in the green fluorescence versus side scatter cytograms was accounted for by using the red fluorescence that distinguishes Prochlorococcus from heterotrophic bacteria as defined here above (Figure 2b) [Sieracki et al., 1995].

\subsection{Biological Impact on Bacterial Distribution}

[22] The nonsynopticity of the sampling may induce some confusion between the temporal shift of the phytoplankton bloom and the bacterial development, generating difficulties in interpreting the bacterial abundance distribution. The study area was thus divided into six regions (Figure 1b) as a compromise between the nonsynopticity of the sampling and the latitudinal differences in hydrological and biological parameters. The Tchla, nitrate and bacteria integrate values were calculated over $300 \mathrm{~m}$ depth, corresponding to the limit of the Tchla sampling. Indeed, some low Tchla concentrations $\left(<0.045 \mathrm{mg}\right.$ Chl $\left.a \mathrm{~m}^{-3}\right)$ were observed at this depth at stations $12,14,17,18,24$, and 77.

[23] Areas 1 and 2 correspond to the northwest and northeast parts of the grid (Figure 1b). Their main characteristics were deep MLDs, high nutrient concentration (2140 \pm $242 \mathrm{mmol} \mathrm{NO}_{3} \mathrm{~m}^{-2}$ (Figure 3b)), low sea surface temperature $\left(\sim 13^{\circ} \mathrm{C}\right)$, shallow isopycnal $\left(26.9 \mathrm{~kg} \mathrm{~m}^{-3}\right.$ at $\left.73 \mathrm{~m}\right)$ and $T \mathrm{chl} a$ integrated values of $48.5 \pm 10.7 \mathrm{mg} \mathrm{Chl} a \mathrm{~m}^{-2}$ (Figure 3a). The maximum average bacterial integrated abundance values were observed in this area (Table 1), with no significant difference between area 1 and area 2 (Table 2). Area 3 was located at the western side of the central study area and was characterized by significantly $(t$ test, $p<0.05)$ higher nutrient and lower Tchla contents: $2387 \pm 601 \mathrm{mmol} . \mathrm{NO}_{3} \mathrm{~m}^{-2}(t=$ $1.98, n=14)$ and $39.5 \pm 8.6 \mathrm{mg} \mathrm{Chl} a \mathrm{~m}^{-2}(t=2.54, n=15)$ respectively as compared to $1986 \pm 368 \mathrm{mmol} . \mathrm{NO}_{3} \mathrm{~m}^{-2}(n=$ $8)$ and $58.6 \pm 7.65 \mathrm{mg} \mathrm{Chl} a \mathrm{~m}^{-2}(n=10)$, in the eastern side respectively (Figures $3 a$ and $3 b$ ). Area 4, situated in the eastern side of the central study area $\left(41^{\circ}-43^{\circ} \mathrm{N}\right)$, was delimited to the west by a longitudinal jet flowing between A1 and C4 [Fernández et al., 2005a] and presented the highest values of $T \mathrm{chl} a$, up to $115 \mathrm{mg} \mathrm{Chl} a \mathrm{~m}^{-2}$ (station 39), near the frontal zone $\left(\sim 41.5^{\circ} \mathrm{N}\right.$ (Figure $\left.3 \mathrm{a}\right)$ ). Bacteria were not significantly more abundant in area 4 (Table 1) than in area 3 (Table 2); the observed small difference was mostly due to LNA that were significantly more abundant in the area 4 (Tables 1 and 2). Area 5 included 

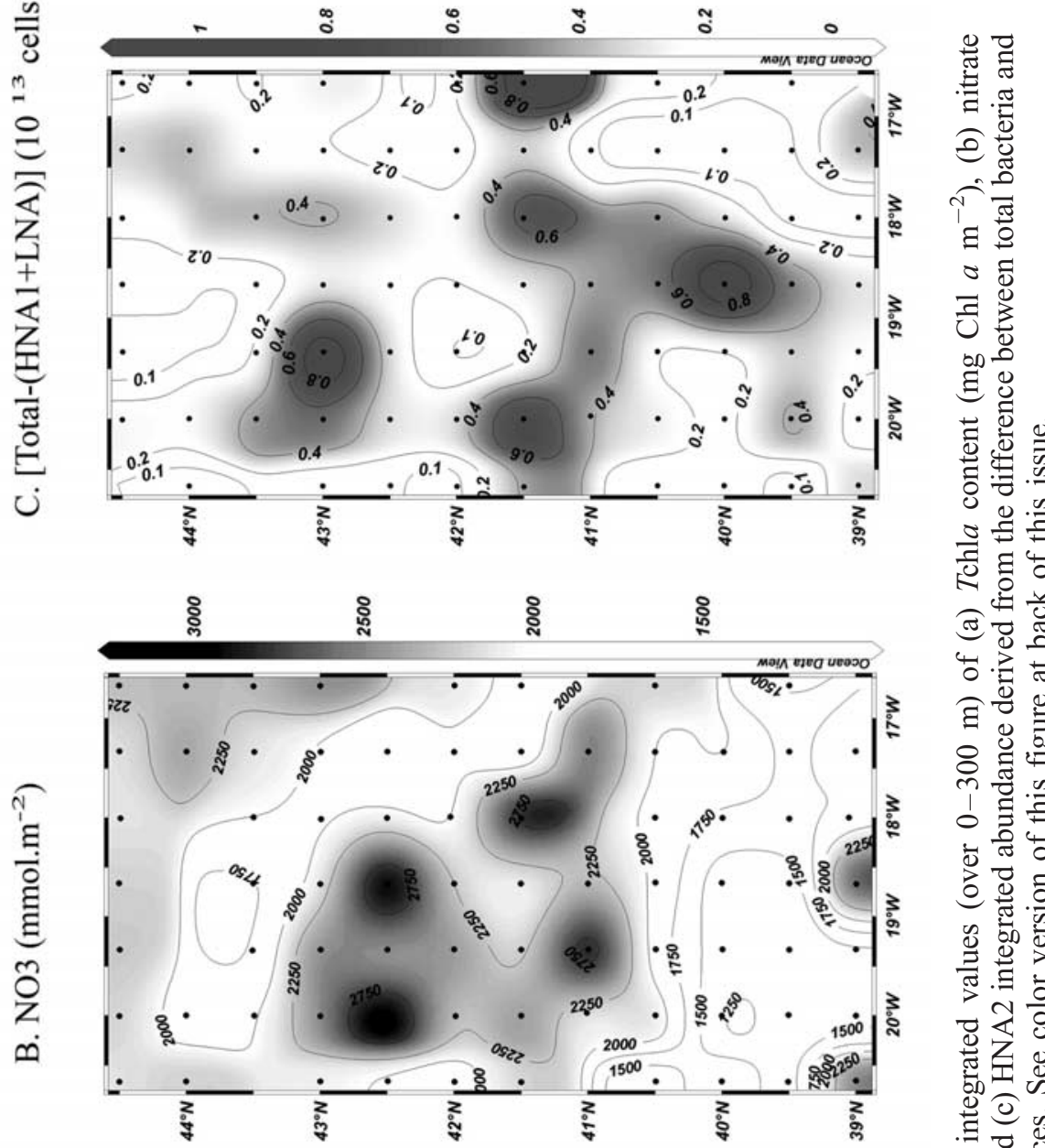

(듀월

馆就

छ

율

司告

- त्

월유.

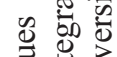

苛 范

중융

荧至

픙

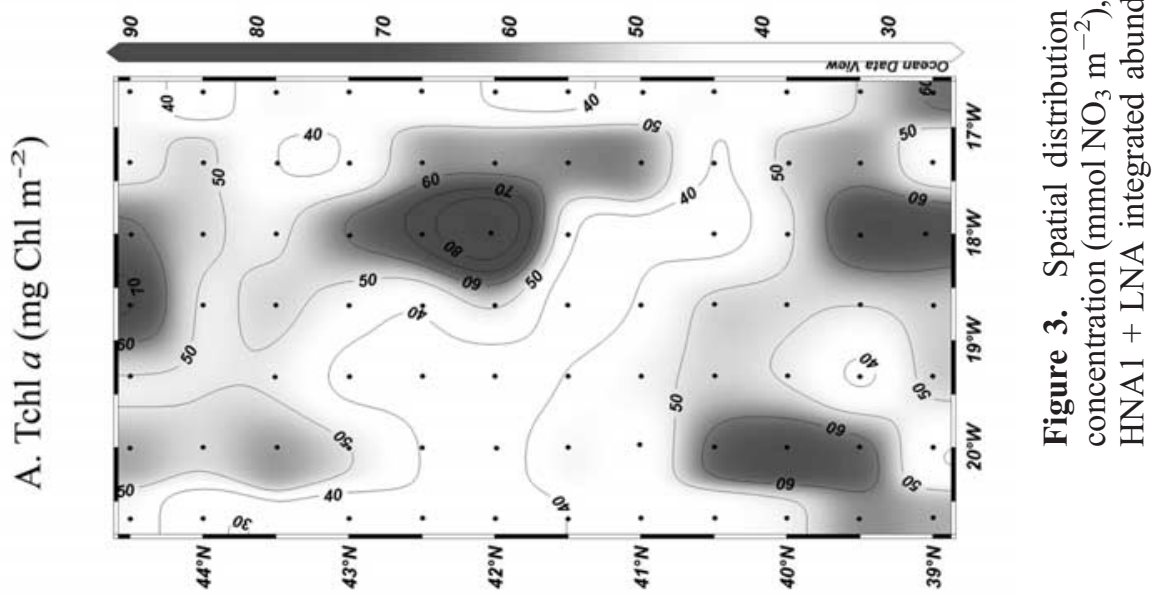


Table 1. Average Integrated Bacteria Concentrations $\pm \mathrm{SD}$ in the Upper $300 \mathrm{~m}$ for the Six Areas Defined in Figure 1

\begin{tabular}{|c|c|c|c|c|c|c|}
\hline Area & $1(n=13)$ & $2(n=11)$ & $3(n=15)$ & $4(n=9)$ & $5(n=16)$ & $6(n=10)$ \\
\hline Average total bacteria, $10^{13}$ cells $\mathrm{m}^{-2}$ & $14.2 \pm 3.16$ & $14.2 \pm 3.16$ & $12.41 \pm 2.18$ & $14.15 \pm 3.03$ & $13.6 \pm 2.72$ & $11.23 \pm 2.61$ \\
\hline Average HNA1, $10^{13}$ cells m ${ }^{-2}$ & $6.56 \pm 1.82$ & $7.24 \pm 1.15$ & $6.03 \pm 1.22$ & $6.40 \pm 1.34$ & $6.62 \pm 1.60$ & $5.07 \pm 2.23$ \\
\hline Average LNA, $10^{13}$ cells $\mathrm{m}^{-2}$ & $7.04 \pm 1.31$ & $7.79 \pm 0.87$ & $5.94 \pm 1.18$ & $7.68 \pm 2.77$ & $6.78 \pm 1.67$ & $5.90 \pm 1.21$ \\
\hline
\end{tabular}

the anticyclonic eddy A2 (Figure 1b) and was characterized by deeper isopycnal $\left(26.9 \mathrm{~kg} \mathrm{~m}^{-3}\right.$ at $\left.230 \mathrm{~m}\right)$, high sea surface temperatures $\left(\sim 16^{\circ} \mathrm{C}\right)$ and high $T$ chl $a$ integrated values (mean $52.2 \pm 10.2 \mathrm{mg} \mathrm{Chl} a \mathrm{~m}^{-2}$ (Figure 3a)) with a maximum $T$ chla concentration of $1.77 \mathrm{mg} \mathrm{Chl} a \mathrm{~m}^{-3}$ at station $71\left(20^{\circ} \mathrm{W}, 20 \mathrm{~m}\right.$ depth). Area 6 occupied the southeastern part of the grid and showed lower Tchla integrated values (mean 48.2 $\pm 12.4 \mathrm{mg} \mathrm{Chl} a \mathrm{~m}^{-2}$ (Figure 3a)). Globally, this southern region (areas 5 and 6) exhibited the lowest integrated concentrations of nutrients (1720 \pm 466 mmol. $\mathrm{NO}_{3} \mathrm{~m}^{-2}$ (Figure $3 \mathrm{~b}$ )). Bacteria were significantly less abundant in the southeast corner than in the southwest corner; in that case, the difference was due to HNA1 that were significantly more concentrated in the A2 area.

[24] The HNA2 were not present down to $300 \mathrm{~m}$ depth at all stations. Consequently, their contribution to the total integrated heterotrophic bacterial abundances was derived from the difference between total bacteria and HNA1 + LNA integrated abundances (Figure $3 \mathrm{c}$ ). They were mostly present in the areas 1, 3 and at the eastern side of A2 in area 5 (Figures $1 \mathrm{~b}$ and $3 \mathrm{c}$ ).

\subsubsection{Bacterial Abundances and Tchla Concentrations} in the Euphotic and Mixed Layers

[25] Either when considering the whole study area or the six zones into which it was subdivided, no significant relationship was observed between abundances of bacterial subpopulations and Tchla concentrations whether in the mixed or the euphotic layer. The positive slope of the regression between log transformed concentrations of bacteria and Tchl $a$ provides evidence for an increase in bacterial abundance following an increase in Tchla concentration [Buck et al., 1996; Cole et al., 1988; see also Li et al., 2004, and references therein]. Most of the analogous slopes reported in the literature are $<1$, but the related studies concerned the whole bacterial community. HNA1 exhibited a slope $\geq 1$ in the ELD of areas 1 and 2 and the MLD of areas 2 and 4 (Table 3 ). Furthermore, slopes corresponding to HNA1 were always higher than that of LNA, except in the MLD around A2 (area 5 (Table 3)).

\subsubsection{Integrated Tchl $a$ and Bacteria Concentrations} Over the Euphotic and Mixed Layer

[26] A significant relationship was found between the MLD and the bacteria abundance integrated over it $\left(r^{2}=\right.$ $0.8, n=69, p<0.01)$, which could be accounted for by large variations of the MLD (from 5 to $216 \mathrm{~m}$, data not shown). Indeed, south of $41^{\circ} \mathrm{N}$, the summer stratification was under progress, inducing an average MLD of $25.7 \pm$ $21.1 \mathrm{~m}$, whereas it was $36.7 \pm 24.6 \mathrm{~m}$ in the central area and $91.6 \pm 52.7 \mathrm{~m}$ north of $43^{\circ} \mathrm{N}$, with a maximum value of $216 \mathrm{~m}$ at $44.5^{\circ} \mathrm{N}-20^{\circ} \mathrm{W}$. The regression between integrated total bacteria abundances (cells $\left.\mathrm{m}^{-2}\right)$ and $T \mathrm{chl} a\left(\mathrm{mg} \mathrm{Chl} \mathrm{a} \mathrm{m}{ }^{-2}\right)$ was found to follow a power function within the MLD (Table 4). When considering separately integrated abundances of HNA1 and LNA, the regression was greater in the central area between 41 and $43^{\circ} \mathrm{N}\left(r^{2}=0.83\right.$ and 0.88 respectively, $p<0.01$ ) than elsewhere (see Table 4 ). The northern area was very rich in bacteria with a maximum integrated abundance of $1.3310^{13}$ cells $\mathrm{m}^{-2}$ and a small difference between HNA1 and LNA integrated abundances $\left(0.45\right.$ and $0.6910^{13}$ cells $\mathrm{m}^{-2}$ respectively for the deepest $\operatorname{MLD}\left(216 \mathrm{~m}\right.$; station 17: $\left.44.5^{\circ} \mathrm{N}, 20^{\circ} \mathrm{W}\right)$ ).

[27] The depth of the euphotic layer did not exhibit such large changes and averaged $52.5 \pm 8 \mathrm{~m}$. No relationship was found between bacteria and $T \operatorname{chl} a$ concentrations integrated over the euphotic layer.

[28] We determined the ratios of integrated (over the mixed and euphotic layers) vertical distributions of bacteria, $T$ chla, and nitrate $\left(\mathrm{IB}_{(\mathrm{MLD})} / \mathrm{IB}_{(\mathrm{ELD})}, \mathrm{IT}_{(\mathrm{MLD})} / \mathrm{IT}_{(\mathrm{ELD})}\right.$, $\mathrm{NO}_{3 \text { (MLD) }} / \mathrm{NO}_{3}$ (ELD) respectively) and plotted these ratios as a function of the ratio (MLD/ELD) of the corresponding layer depths (Figure 4).

[29] When the MLD was deeper than the ELD (MLD/ ELD $>1)$, the ratios $\mathrm{IB}_{(\mathrm{MLD})} / \mathrm{IB}_{(\mathrm{ELD})}$ and $\mathrm{IT}_{(\mathrm{MLD})} / \mathrm{IT}_{(\mathrm{ELD})}$ deviated below the bisecting line. This was more pronounced for the $\mathrm{IT}_{(\mathrm{MLD})} / \mathrm{IT}_{(\mathrm{ELD})}$ ratio, because ELD was derived from the Tchla vertical distribution. Stations with such ratios were located in the northern part of the study area. The Tchl $a$ concentration integrated over the upper $300 \mathrm{~m}$ reached $78 \mathrm{mg}$ chl $a \mathrm{~m}^{-2}$ at station 15 , well above the average value of $48.7 \pm 13.68 \mathrm{mg}$ chl $a \mathrm{~m}^{-2}$. The $\mathrm{IB}_{(\mathrm{MLD})} / \mathrm{IB}_{(\mathrm{ELD})}$ ratios located below the bisecting line corresponded to stations in the central area, particularly around A1 (stations 40, 42, 39).

[30] For MLD/ELD values in the range $0.5-1$, the $\mathrm{IB}_{(\mathrm{MLD})} / \mathrm{IB}_{(\mathrm{ELD})}$ ratios located above the bisecting line highlight the fact that the mixed layer, though shallower than the euphotic layer, was concentrating an important fraction of the bacteria. Some associated $\mathrm{NO}_{3(\mathrm{MLD})} /$ $\mathrm{NO}_{3 \text { (ELD) }}$ ratios were located below the bisecting line, expressing the role of barrier played by the bottom of the MLD with respect to the biological community. Stations corresponding to that situation were associated to strong jets observed around C4 and A2 (Figure 1b) [Fernández et al., 2005a] and in the frontal zone separating these two eddies.

[31] When MLD/ELD was $<0.5$, the mixed layer was very shallow and the related stations were located in the region of the A2 gyre (Figure $1 b$ ).

\subsubsection{Vertical Distribution of Bacteria}

Subpopulations (HNA1 and LNA)

[32] When considering the whole study area the average distributions of HNA1 and LNA appeared not significantly different above $100 \mathrm{~m}$ and below $300 \mathrm{~m}$ depth (not shown)

Table 2. Relationships Between Averages Integrated Bacteria Concentrations From Distinct Areas

\begin{tabular}{ccc}
\hline Total Bacteria & LNA & HNA1 \\
\hline$(1+2)>(3=4)$ & $3<4^{\mathrm{a}}$ & $3=4$ \\
$(1+2)>\left(5>6^{\mathrm{a}}\right)$ & $5=6$ & $5>6^{\mathrm{b}}$ \\
\hline${ }^{\mathrm{a}}$ T test $p<0.02$. & & \\
${ }^{\mathrm{b}}$ T test $p<0.03$ & &
\end{tabular}


Table 3. Values of Slope and $y$ Intercept of the Linear Regression Between $\log _{10}$ (HNA1 or LNA Abundance) and $\log _{10}$ (Tchla Concentration) Over the Mixed and Euphotic Layers of the Six Regions Defined in Figure 1

\begin{tabular}{lcccccc}
\hline & \multicolumn{7}{c}{ Area (Figure 1) } \\
\cline { 2 - 7 } $\log ($ bacteria $)=a \log (T \mathrm{chl} l a)+b$ & 1 & 2 & 3 & 4 & 5 & 6 \\
\hline & $E L D$ & & & & & \\
HNA1 & & & & & & \\
$\quad$ Slope $(a)$ & 1.55 & 1.00 & 0.98 & 0.86 & 0.57 & 0.87 \\
$\quad y$ intercept $(b)$ & 5.94 & 5.83 & 5.80 & 5.66 & 5.64 & 5.54 \\
LNA & & & & & & \\
$\quad$ Slope $(a)$ & 1.37 & 0.65 & 0.69 & 0.69 & 0.45 & 0.72 \\
$y$ intercept $(b)$ & 5.91 & 5.72 & 5.63 & 5.60 & 5.56 & 5.56 \\
& & & & & & \\
& $M L D$ & & & & & \\
HNA1 & & & & & & \\
$\quad$ Slope $(a)$ & 0.58 & 1.13 & 0.82 & 1.13 & 0.41 & 0.67 \\
$y$ intercept $(b)$ & 5.70 & 5.89 & 5.68 & 5.71 & 5.39 & 5.51 \\
LNA & & & & & & \\
$\quad$ Slope $(a)$ & 0.49 & 0.87 & 0.51 & 0.93 & 0.47 & 0.50 \\
$y$ intercept $(b)$ & 5.68 & 5.80 & 5.50 & 5.64 & 5.35 & 5.48 \\
\hline
\end{tabular}

whereas between 100 and $300 \mathrm{~m}$ depth, HNA1 were less abundant (maximal average difference of $13.5 \%$ at $150 \mathrm{~m}$ depth) than LNA $(t=-13.9, p<0.001, n=578)$. Below the MLD, LNA were more abundant than HNA1 (50.71 \pm $8.07 \%$ and $47.98 \pm 8.06 \%, t=-6.34, p<0.001, n=$ 696). In Figure 5 are displayed the vertical average distributions of HNA1 and LNA abundances (Figures $5 \mathrm{a}, 5 \mathrm{~d}, 5 \mathrm{~g}$, $5 \mathrm{j}, 5 \mathrm{~m}$, and $5 \mathrm{p}$ ), their relative percentages (Figures $5 \mathrm{~b}, 5 \mathrm{e}$, $5 \mathrm{~h}, 5 \mathrm{k}, 5 \mathrm{n}$, and $5 \mathrm{q}$ ) and the $T \mathrm{chl} a$ vertical distribution (Figures 5c, 5f, 5i, 51, 5o, and 5r) for each of the six regions defined in Figure 1b. In the northern study area (areas 1 and 2 of Figure 1b), the distributions of both subpopulations were not significantly different in the upper $100 \mathrm{~m}$ (Figures $5 \mathrm{a}, 5 \mathrm{~b}, 5 \mathrm{~d}$, and $5 \mathrm{e}$ ), which can be accounted for by the presence of large MLDs. In contrast, HNA1 percentages in the upper $100 \mathrm{~m}$ were significantly higher than LNA percentages in the center west (area 3,t $t=5.36, p<0.01$, $n=8$ (Figures $5 \mathrm{~g}$ and $5 \mathrm{~h}$ )) and in the southwest (area 5; $t=$ 4.10, $p<0.01, n=8$ (Figures $5 \mathrm{~m}$ and $5 \mathrm{n}$ )) while LNA percentages were significantly higher than HNA1 percentages in the southeast (area 6; $t=4.63, p<0.01, n=$ 8 (Figures $5 \mathrm{p}$ and $5 \mathrm{q}$ )). Between 100 and $300 \mathrm{~m}$ depth, LNA were significantly more abundant than $\operatorname{HNA} 1(t=10.4, p<$ $0.01, n=19$ ) except for the center west (area 3 (Figure 5h)). Underneath the highest surface Tchla concentrations (center east (area 4 (Figure 5k)) and southwest (area 5 (Figure 5n)), both subgroups were significantly distinct from each other between $100 \mathrm{~m}$ to $400 \mathrm{~m}(t=5.47$ and $t=5.68$ respectively, $p<0.001, n=5$ ), with maximal percentages for LNA.

\subsection{Evidence of Physical and/or Biological Influence on Integrated Bacteria Distributions}

[33] Figure 6 displays the spatial distribution of integrated abundances of HNA1 and LNA over $300 \mathrm{~m}$ depth superimposed on the upper layer geostrophic current field together with the locations of the main cyclonic (C4) and anticyclonic structures (A1 and A2). The spring cruise was characterized by high geostrophic current values and a strong northward jet was observed along the eastern edge of $\mathrm{C} 4$ and the western edge of $\mathrm{A} 1\left(\sim 0.2 \mathrm{~m} \mathrm{~s}^{-1}\right)$. Two southward jets were observed at the western edge of $\mathrm{C} 4$ and at the eastern edge of A1 (Figures 6a and 6b).
[34] The distribution of LNA integrated values was influenced by the main geostrophic currents, as suggested by the low abundance values observed between $\mathrm{C} 4$ and $\mathrm{A} 1$ and the high abundance values on the eastern side of A2 (Figure 6a). The HNA1 integrated abundance values also matched the fingerprint of these currents to some extent, but the observed relationship was less obvious in that case. Indeed, high values of HNA1 integrated abundances were observed at $42^{\circ} \mathrm{N}$, encompassing the northward jet. Tchla was present in high concentrations in this area as shown in Figure 3a. In the region occupied by A2, the distribution of HNA1 and LNA integrated values was bearing the anticyclonic signature.

\subsection{Mesoscale Effect on Bacterial Distribution: Multiple Correspondence Analysis}

[35] Two successive multiple correspondence analyses (MCA) were applied to provide and quantify evidence for the mesoscale impact on bacterial distribution. The first MCA included the whole data set: categorizing the nutrient variables, the bacterial subpopulation variables, depth, temperature, density and fluorescence. Results did not reveal any mesoscale impact on the bacterial community, essentially because of the occurrence of a Guttman effect (not shown), implying a major role of the first axis and all the other axes being a function of the first one, in agreement with the previous correlation results.

[36] In the second MCA, the number of parameters was limited and we took advantage of the possible links observed between bacterial integrated distribution and geostrophic currents delimiting the main hydrodynamical features (Figure 6a). To this purpose, the study area was divided into nine regions as depicted in Figure 7 , corresponding roughly to hydrodynamical rather than biogeochemical characteristics as previously done. These subdivisions, based on a subjective visual compromise between bacteria distribution and hydrodynamical features, are as follow: (1) NE and (2) NW in the northern area, (3) CW1 and (4) CW2 representing the eastern and western side of $\mathrm{C} 4$ respectively, (5) $\mathrm{CE}$ covering the center east and partially including $\mathrm{A} 1$ and the frontal zone around $41.5^{\circ} \mathrm{N}$, (6) FR, the frontal zone separating $\mathrm{C} 4$ from $\mathrm{A} 2$, (7) $\mathrm{A} 2 \mathrm{~W}$ and (8) A2E the western and eastern sides of A2 respectively and finally (9) SE, the southeast corner of the study area.

Table 4. Relationships Within the Mixed Layer of Different Regions, Between Integrated Bacteria Abundance (IB) and Integrated Tchla (IT) ${ }^{\mathrm{a}}$

\begin{tabular}{|c|c|c|c|c|c|c|}
\hline \multirow[b]{2}{*}{ Area } & \multirow{2}{*}{$\begin{array}{c}\text { Bacteria } \\
\text { Distribution }\end{array}$} & \multirow{2}{*}{$\begin{array}{l}\text { Average Mixed } \\
\text { Layer Depth, m }\end{array}$} & \multirow[b]{2}{*}{$n$} & \multicolumn{2}{|c|}{$\mathrm{IB}=a \mathrm{IT}$} & \multirow[b]{2}{*}{$r^{2}$} \\
\hline & & & & $a$ & $b$ & \\
\hline Study area & IB $_{\text {Total }}$ & & 70 & $8.09 \mathrm{E}+11$ & 1.16 & 0.80 \\
\hline \multirow[t]{2}{*}{ North of $43^{\circ} \mathrm{N}$} & $\mathrm{IB}_{\mathrm{HNA1}}$ & $91.6 \pm 52.7$ & 23 & $5.23 \mathrm{E}+11$ & 1.12 & 0.68 \\
\hline & $\mathrm{IB}_{\mathrm{LNA}}$ & $91.6 \pm 52.7$ & 23 & $4.04 \mathrm{E}+11$ & 1.20 & 0.73 \\
\hline \multirow[t]{2}{*}{$\begin{array}{l}\text { Central area } \\
\left(41^{\circ}-43^{\circ} \mathrm{N}\right)\end{array}$} & $\mathrm{IB}_{\text {HNA1 }}$ & $36.7 \pm 24.6$ & 21 & $7.37 \mathrm{E}+11$ & 0.95 & 0.83 \\
\hline & $\mathrm{IB}_{\mathrm{LNA}}$ & $36.7 \pm 24.6$ & 21 & $7.59 \mathrm{E}+11$ & 0.89 & 0.88 \\
\hline \multirow[t]{2}{*}{ South of $41^{\circ} \mathrm{N}$} & $\mathrm{IB}_{\mathrm{HNA} 1}$ & $25.7 \pm 21.1$ & 25 & $2.18 \mathrm{E}+11$ & 1.01 & 0.63 \\
\hline & $\mathrm{IB}_{\mathrm{LNA}}$ & $25.7 \pm 21.1$ & 25 & $5.01 \mathrm{E}+11$ & 1.28 & 0.58 \\
\hline
\end{tabular}

${ }^{\mathrm{a}} \mathrm{IB}_{\text {Total }}$, integrated total bacteria abundance; $\mathrm{IB}_{\mathrm{HNAl}}$, integrated HNA1 abundance; $\mathrm{IB}_{\mathrm{LNA}}$, integrated LNA abundance. IB is in cells $\mathrm{m}^{-2}$ and IT is in $\mathrm{mg} \mathrm{Chl} a \mathrm{~m}^{-2}$. 


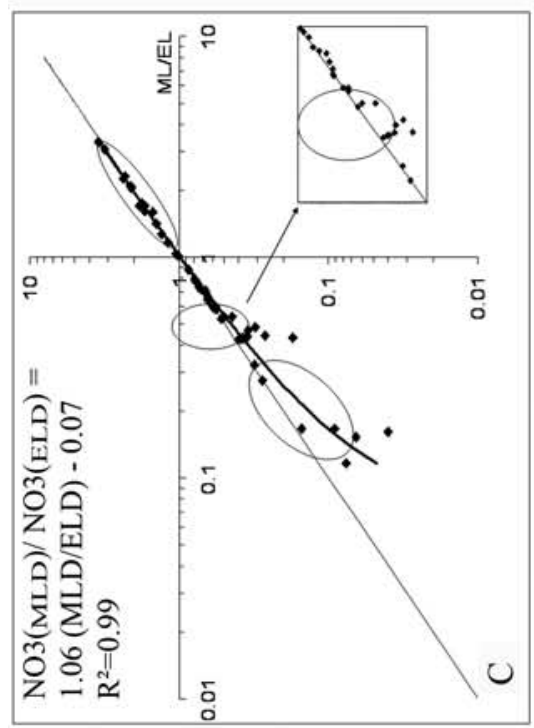

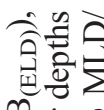

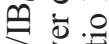

空要

요요

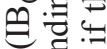

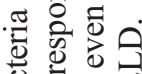

论

తิ)

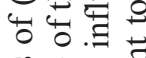

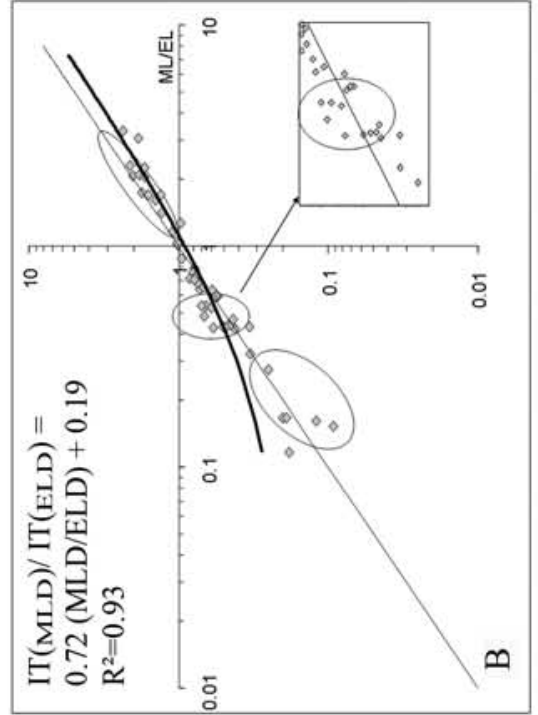

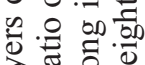

空茟

造它

눙 명

웡.음

吉导主

可 0

当 ิิ

塞

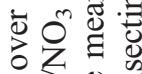

氙.

赵 00

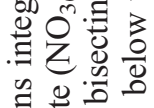

总要导

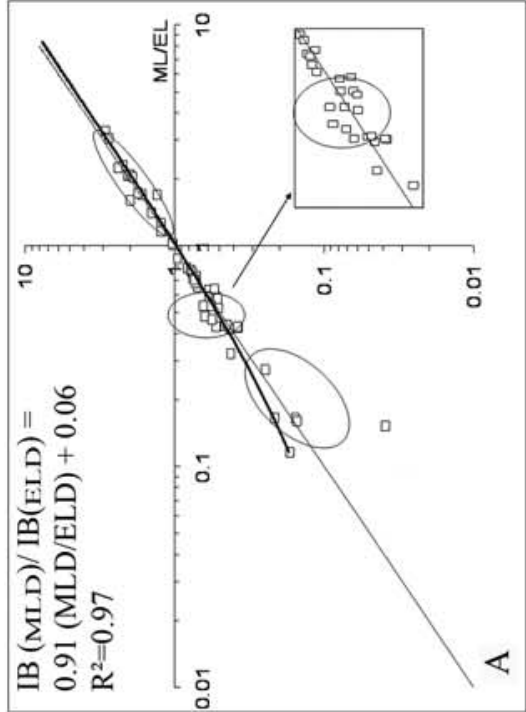

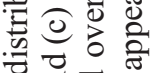

च्च च

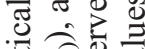

总守要

낭분

.

四完

을

궁

路包星 


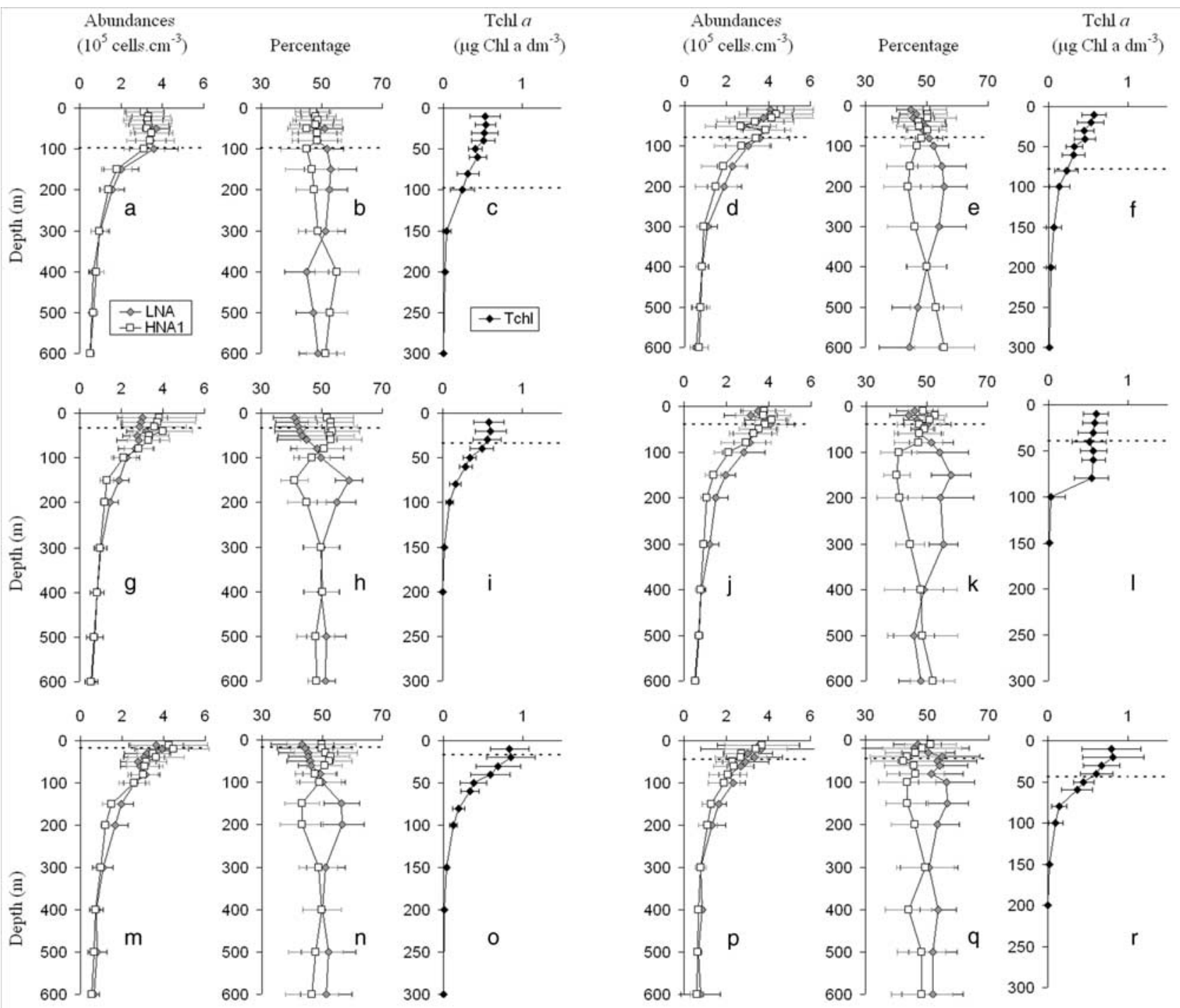

Figure 5. Vertical abundance $\left(10^{6}\right.$ cells $\left.\mathrm{cm}^{-3}\right)$ distribution of heterotrophic bacterial subpopulations and Tchla concentration in the study area subdivided into six parts (see Figure 1b). Each graphic number is related to the region number used in Figure 1b. Dotted lines represent the average MLD of the region. For each of these divisions: (a, d, g, j, m, p) average vertical profiles \pm SD of HNA1 and LNA abundances; (b, e, h, $\mathrm{k}, \mathrm{n}, \mathrm{q}$ ) average vertical profiles \pm SD of HNA1 and LNA relative abundance percentages; and (c, f, i, l, o, r) average vertical profiles $\pm \mathrm{SD}$ of $T \mathrm{chl} a$ concentrations. Note that the depth scale for $T \mathrm{chl} a$ is different from that for bacteria.

[37] The large data set of bacterial abundance does not provide evidence for a large variability that would differentiate biotic or abiotic factors. To study the mesoscale impact on the bacterial population, we used two approaches based on (1) total bacterial abundances and (2) subgroup percentages respectively. Therefore we determined six classes of stations corresponding to values greater than the average \pm standard deviation (extreme values) for each depth at each station (Table 5). Thus both MCAs were run involving four factors each: (1) regions (Figure 7), $A b d c>, A b d c 200 \mathrm{~m}>$ and $A b d c<$ (Table 5) and (2) regions (Figure 7), HNA1>, LNA> and HNA2> (Table 5). Each parameter of Table 5 was expressed by two modes (present or absent). These modalities were organized in a disjunctive table and then plotted after calculating their correspondences.

\subsubsection{Contrasts in the Bacterial Distribution} Through Extreme Situations: The MCA Classes

[38] The six classes described in Table 5 were contrasting with the average bacterial distribution and provided evidence for abundance variability. Bacteria at stations belonging to $A b d c>$ class (Table 5) were $29 \%$ more concentrated while bacteria at stations belonging to $A b d c<$ class were $25 \%$ less concentrated than the average bacterial concentrations over the whole study area. Stations belonging to $A b d c 200 \mathrm{~m}>$ were grouping the extreme values below $200 \mathrm{~m}$ depth among those used to select $A b d c>$ stations. These bacteria maximal abundances below $200 \mathrm{~m}$ essentially corresponded to LNA $\left(1.72 \times 10^{5}\right.$ cells $\mathrm{cm}^{-3}$ against $0.793 \times 10^{5}$ cells cm$^{-3}$ for the overall average value). HNA1 were also present in higher concentrations than the 

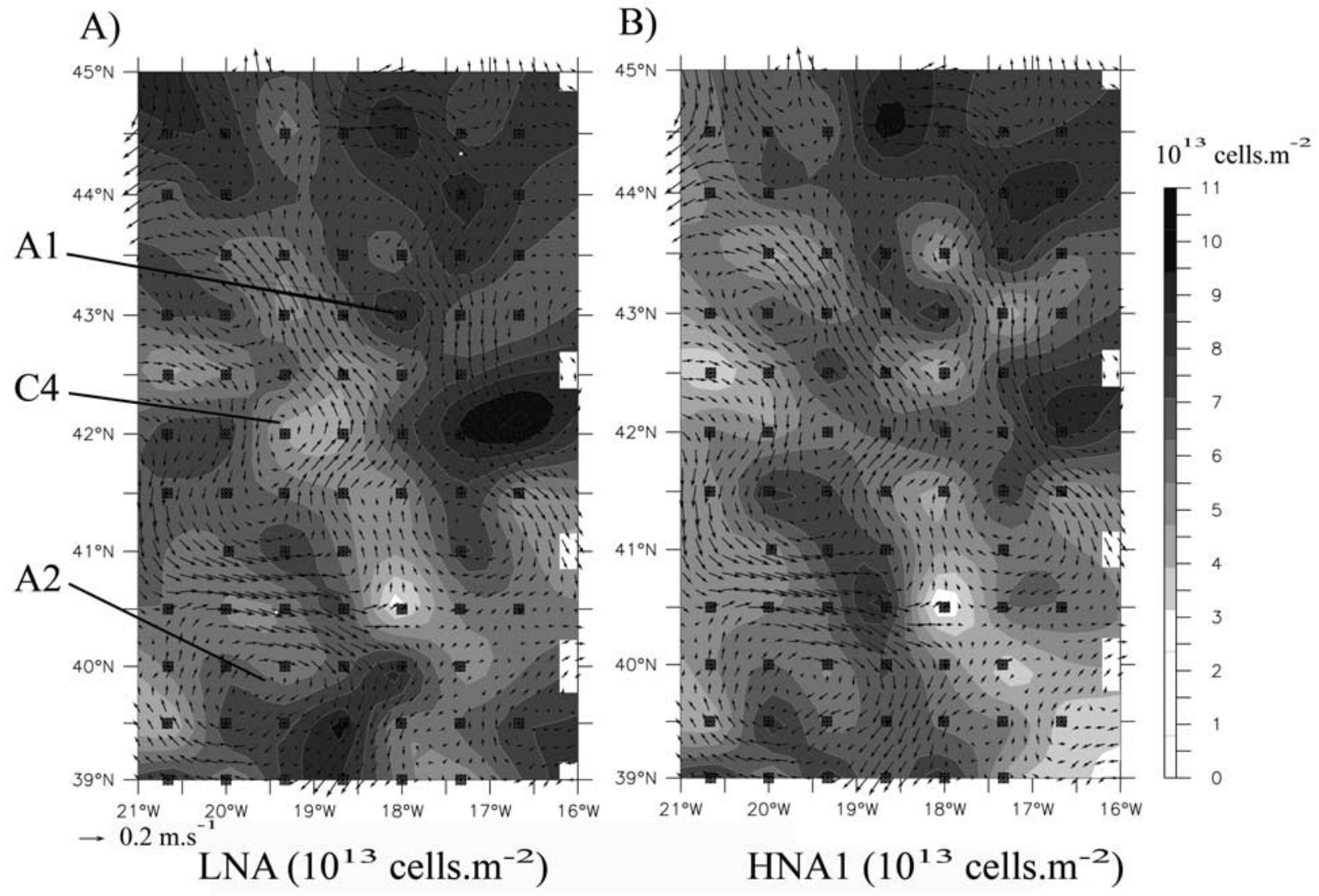

Figure 6. Upper layer geostrophic current field superimposed on the bacteria abundances integrated between 0 and $300 \mathrm{~m}$ depth. (a) LNA integrated values $\left(10^{13}\right.$ cells $\left.\mathrm{m}^{-2}\right)$. (b) HNA1 integrated values $\left(10^{13}\right.$ cells $\left.\mathrm{m}^{-2}\right)$. Labeled mesoscale features: A1 and A2, anticyclonic gyre; $\mathrm{C} 4$, cyclonic gyre. See color version of this figure at back of this issue.

overall average $\left(1.24 \times 10^{5}\right.$ cells $\mathrm{cm}^{-3}$ against $0.75 \times$ $10^{5}$ cells $\mathrm{cm}^{-3}$ ).

[39] Stations belonging to the HNA1> class (Table 5) were characterized by an average HNA1 abundance percentage of $59.5 \%$ to be compared to $48.2 \%$ for the whole data set and HNA1 made the major subpopulation in the upper $100 \mathrm{~m}$ (not shown). Below $100 \mathrm{~m}$ depth, HNA1 and LNA bacteria abundances were very close. Stations belonging to the $L N A>$ class were characterized by an average LNA abundance percentage of $61.0 \%$ compared to $49.7 \%$ for the whole data set. At these stations, LNA made the dominant subpopulation over the sampled water column, with a maximum percentage of $72.0 \%$ at $150 \mathrm{~m}$ depth (not shown).

[40] The MLD was shallower at stations belonging to the $H N A 1>$ class than at stations of the $L N A>$ class ( $35.7 \pm$ $26.4 \mathrm{~m}(n=294)$ against $46.7 \pm 30.7 \mathrm{~m}(n=274)$ respectively, $t=4.53, p<0.001)$. The HNA1> stations exhibited $T \operatorname{chl} a$ average contents in the upper $50 \mathrm{~m}$ significantly higher than at $L N A>$ stations $(0.64 \pm 0.09$ $(n=100)$ against $0.54 \pm 0.05 \mathrm{mg} \mathrm{Chl} a \mathrm{~m}^{-3}(n=105)$ respectively, $t=2.72, p<0.01$ ). No significant difference was observed between $H N A 1>$ and $L N A>$ stations regarding nitrate concentration values.
[41] Stations belonging to the $H N A 2>$ class did not provide evidence of large differences with stations belonging to the $H N A 1>$ class regarding hydrological data or nutrient concentrations. However, stations characterized by two HNA2 extreme abundance values instead of one (Table 5), were associated to higher values of nitrate in the upper $100 \mathrm{~m}$ than the HNA1> class stations $(4.78 \pm$ $2.07(n=69)$ and $3.87 \pm 2.44(n=157) \mu \mathrm{M} \mathrm{NO}$ respectively, $t=4.26, p<0.001)$.

3.5.2. Combined Results of the Two MCA Approaches

[42] Extreme high abundances were observed close to the extreme abundances below $200 \mathrm{~m}$ (Figure 8a), suggesting that the influencing high abundances were occurring below $200 \mathrm{~m}$ depth. The box-and-whisker plot of HNA1 and LNA abundances with respect to latitude (Figure 9) shows that the main influence comes from LNA that were particularly abundant $\left(>2.10^{5}\right.$ cells cm$\left.~^{-3}\right)$ in the $200-400 \mathrm{~m}$ layer in the south. High bacteria concentrations in deep waters also occurred in the northeast region where the mixed layer was very deep $($ mean $=117 \mathrm{~m})$, and Tchla high $(0.05 \pm$ $0.07 \mathrm{mg} \mathrm{m}^{-3}$ at $200 \mathrm{~m}$ against $0.01 \pm 0.02 \mathrm{mg} \mathrm{m}^{-3}$, average value). Maximal abundances were mainly found at $\mathrm{A} 2 \mathrm{~W}$ and A2E, and very weak bacterial abundances were found at SE (Figure 8a). NE area was heterogeneously grouping extreme 


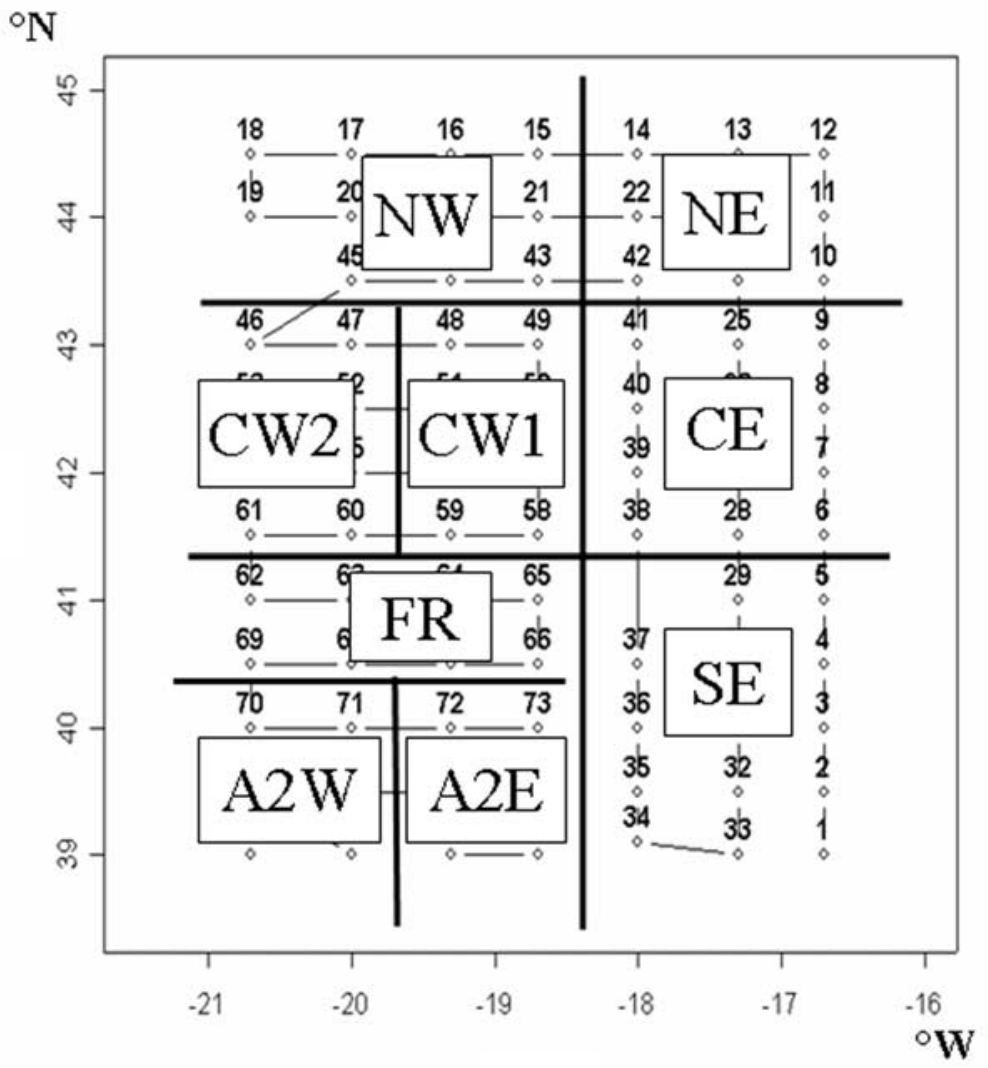

Figure 7. Subdivision of the study area into nine regions to observe the physical impact on bacterial distribution based on geostrophic currents, eddies, and fronts illustrated in Figure 6.

abundances, while the other areas were more or less represented by these classes. CW1 and FR areas were influenced by high abundances and by the zero modalities representing nonextreme situations (Figure 8a). HNA2> and $L N A>$ modalities appeared on the same side of axis 2, separated from the $H N A 1>$ modality (Figure $8 \mathrm{~b}$ ). HNA1> modality was linked to $\mathrm{CW} 1$ and $\mathrm{A} 2 \mathrm{~W}$ (Figure $8 \mathrm{~b}$ ) where strong jets were observed, implying very low percentages of LNA cells in these areas. Both HNA1> and HNA2> modalities were connected to $\mathrm{FR}$, the one region where both modalities were well represented. HNA2> were mostly found in frontal and strong jet areas (FR, CE, A2E) (Figure 8b). LNA $>$ modality was connected to $\mathrm{SE}$ and CW2 (Figure 8b), and to NE where deep mixed layers were observed. NW was linked to the zero modalities (Figure 8b).

\section{Discussion}

\subsection{Community Heterogeneity}

[43] Bacteria are the main contributors to recycling DOC by their high mineralization rate, creating feedbacks of

Table 5. Definition of the Different Classes Corresponding to Extreme Situations

\begin{tabular}{|c|c|c|c|}
\hline Classes & $\begin{array}{l}\% \text { Average Difference } \\
\text { With Total }\end{array}$ & Description & $n$ \\
\hline $\mathrm{Abdc}<$ & -25 & $\begin{array}{c}\text { stations where total bacterial abundance was }<\text { [mean abundance for the whole study area }-\mathrm{SD}] \\
\text { for at least four depths (average of } 13 \text { sampled depths) }\end{array}$ & 13 \\
\hline$A b d c>$ & +29 & $\begin{array}{c}\text { stations where total bacterial abundance was }>\text { [mean abundance for the whole study area }+ \text { SD] } \\
\text { for at least four depths (average of } 13 \text { sampled depths) }\end{array}$ & 20 \\
\hline Abdc $200 \mathrm{~m}>$ & +13 & $\begin{array}{c}\text { stations where the total bacterial abundance was }>[\text { mean }+\mathrm{SD}] \text { below } 200 \mathrm{~m} \text { for at least two depths } \\
\text { (average of five sampled depths) }\end{array}$ & 11 \\
\hline HNA1> & +11.3 & $\begin{array}{c}\text { stations where HNA } \% \text { of the total was }>\text { [mean HNA } \% \text { for the whole study area }+ \text { SD] } \\
\text { for at least three depths (average of } 13 \text { sampled depths) }\end{array}$ & 23 \\
\hline LNA> & +11.3 & $\begin{array}{l}\text { stations where LNA } \% \text { of the total was }>\text { [mean LNA } \% \text { for the whole study area }+ \text { SD] } \\
\text { for at least three depths (average of } 13 \text { sampled depths) }\end{array}$ & 22 \\
\hline HNA2> & +61 & $\begin{array}{c}\text { stations where HNA2 abundance was }>\text { [mean HNA2 abundance for the whole study area }+\mathrm{SD}] \\
\text { for one depth or more }\end{array}$ & 22 \\
\hline
\end{tabular}




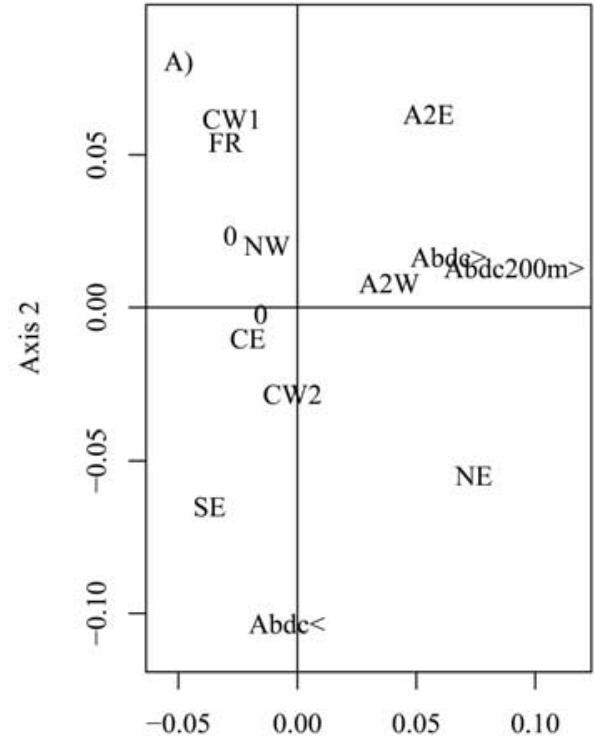

Axis 1

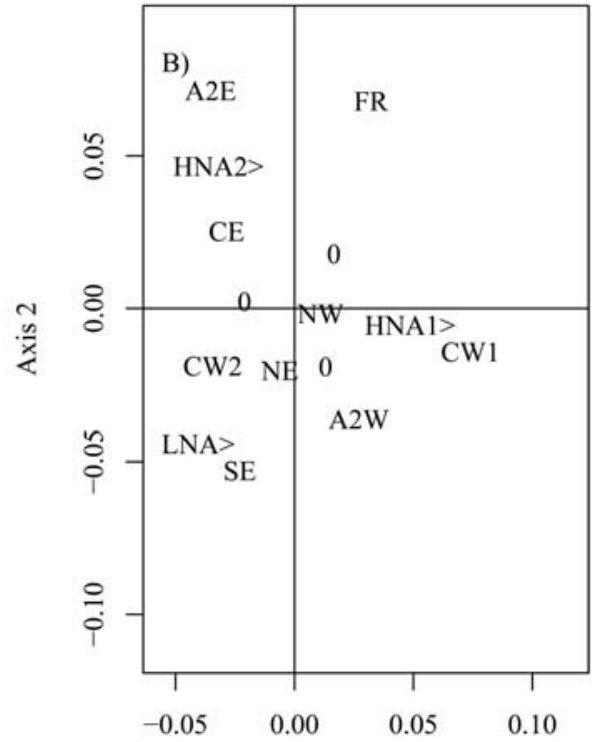

Axis 1

Figure 8. (a) Multiple correspondence analysis (MCA) of extreme bacterial abundances (see Table 5) and geographical areas (see Figure 7). Axis 1 describes $37.47 \%$ of the variability, and axis 2 describes $33.65 \%$. (b) MCA of bacterial extreme subgroup abundances (see Table 5) and geographical areas. Axis 1 describes $22.49 \%$ of the variability, and axis 2 describes $19.17 \%$.

carbon and nutrients in the photic layer within the microbial trophic network.

[44] The three cytometrically distinguished subgroups were dominant in different layers of the water column.
This suggests the existence of different ecological environments supporting distinct microbial assemblages where one of these three subgroups would play a key role. The heterogeneity in their activity is likely influenced by the
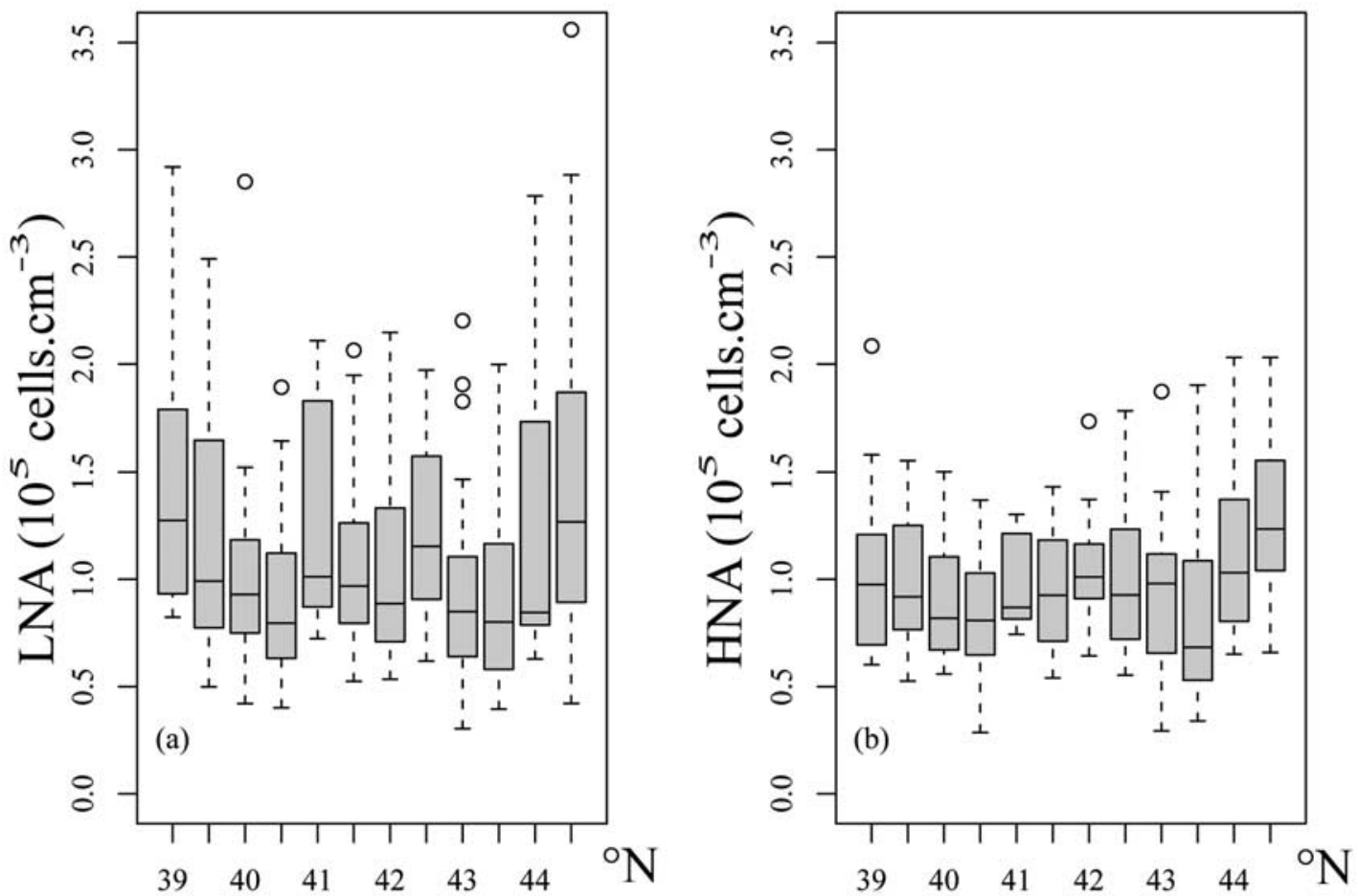

Figure 9. Box-and-whisker plots of the HNA1 and LNA abundances $\left(10^{5}\right.$ cells $\left.\mathrm{cm}^{-3}\right)$ between 200 and $400 \mathrm{~m}$ depth as a function of the latitude. 
status of the surrounding and interacting environment (nutrient depletion, grazing, temperature, hydrodynamism) making critical the cell ability for adaptation.

\subsection{Heterogeneity Between Bacteria and $T \operatorname{chl} a$}

[45] The highest Tchla integrated values found in the center east part of the study area were well correlated to bacterial integrated abundances over the mixed layer (Table 5). No significant correlations were observed on the same areas when we took the concentrations values instead of the integrated values of both parameters, as observed in other temperate areas [Cole et al., 1988; Simon et al., 1992]. Thus there is an indirect relationship between bacteria and chlorophyll spatial distribution, maintained inside of the mixed layer. The large variability observed for Tchl $a$ and bacteria concentrations can be assigned to different stages of the phytoplankton bloom and the subsequent organic matter release [Barbosa et al., 2001] or to the interactions inside the microbial loop (nutrient competition [Fuhrman, 1992], turnover rate between bacteria and phytoplankton [Cho and Azam, 1988; Fuhrman et al., 1989], and diel periodicity of bacteria [Kuipers et al., 2000]) that were likely varying throughout the study area upon the effect of latitudinal variations of hydrological and biogeochemical parameters.

[46] The main occurrence in the surface layer of the highest HNA1 concentrations and the high slopes of the log-log relationship (Table 3) could be explained by the nutritional support from phytoplankton, i.e., high Tchla and nutrient contents. In the upper $300 \mathrm{~m}$, HNA1 and Tchla Spearman's rank correlation was $0.64(n=400, p<0.0001)$. LNA abundance was correlated to $T \operatorname{chl} a$ concentration in the same layer (Spearman, $r=0.57, n=400, p<0.0001$ ) as well as to the Tchla integrated over the mixed layer (Table 4), so that LNA may also respond to organic matter supplied by phytoplankton growth, may be through sloppy feeding [Banse, 1995] of the larger cells (i.e., HNA1 and HNA2). Indeed, the implication of LNA cells in organic matter recycling through bacterivory is known to be less important than for larger cells [del Giorgio et al., 1996]. Furthermore, LNA were more abundant below $100 \mathrm{~m}$ depth (Figures 5b, 5e, 5h, 5k, 5n, and $5 q$ ), suggesting that their abundance could respond to the upper layer trophic status and influence the remineralization processes in deep layers. Indeed, three locations with large LNA abundance can be noticed in Figure 9. They were associated with $(1)$ the northern $\left(>44^{\circ} \mathrm{N}\right)$ region characterized by a deep MLD, (2) the central part $\left(41^{\circ}-42.5^{\circ} \mathrm{N}\right)$ where Tchl $a$ was high and where frontal areas were encountered, and (3) the south $\left(<39.5^{\circ} \mathrm{N}\right)$ where high Tchla concentrations were linked to the A2 anticyclonic eddy and where high sinking particle rates were observed at $400 \mathrm{~m}$ [Leblanc et al., 2005; Guieu et al., 2005].

[47] HNA2 extreme concentrations (Table 5) were located in higher nutrient domains and they exhibited weak correlations with Tchla (Spearman's $r=0.41, n=229, p<$ $0.0001)$.

\subsection{Zoning and the Different Stages of the Phytoplankton Bloom}

[48] Siegel et al. [1990] and Frazel and Berberian [1990] provided evidence for a northward progression over 3 weeks to 1 month of the spring bloom in the North Atlantic Gyre.
During the POMME spring cruise, three main zones could be distinguished: (1) north of $43^{\circ} \mathrm{N}$, reflecting the late winter impact, (2) in the center, corresponding to frontal systems, and (3) south of $41^{\circ} \mathrm{N}$, on the way to the common summer oceanic conditions. Siegel et al. [2002] defined a transition line at $40^{\circ} \mathrm{N}$. South of it, the MLD did not vary enough to support Sverdrup's hypothesis on phytoplanktonic bloom enhancement by the shallowing of the MLD. Thus spring phytoplanktonic production would depend more on the quantity of nutrients supplied by winter mixing than on irradiance availability.

[49] The northern area (areas 1 and 2 (Figure 1b)) where the mixed layer was the deepest, exhibited no significant difference between HNA1 and LNA percentages in the upper $100 \mathrm{~m}$ (Figures $5 \mathrm{~b}$ and 5e). High bacterial concentrations were observed (Figures $6 \mathrm{a}$ and $6 \mathrm{~b}$ ) while Tchla values were diluted through the water column, that could explain the slopes $>1$ observed over the euphotic layer (Table 3). This suggests that the potential dissolved organic matter that would sustain these huge bacteria concentrations may not only find its source from sloppy feeding or phytoplankton exudation that accounts for $2 / 5$ and $1 / 10$ respectively of bacterial carbon solubilization [Banse, 1995]. The possible lack of a direct source of nutrient for bacteria would implicate the role of the winter permanent MLD in supplying organic matter to the upper layer. This organic matter could have been accumulated since the previous fall period (R. Fukuda-Sohrin and R. Sempéré, Seasonal distribution in total organic carbon in the northeast Atlantic in 2000-2001, submitted to Journal of Geophysical Research, 2004) and made more labile through further exposure to UVB radiation [Häder et al., 1998] in conjunction with the impact of turbulence [Peters et al., 2002] enhanced in the northern mixed layer. In the case of deep mixed layers, the phytoplankton growth rate is decreased [Sverdrup, 1953], and the phytoplankton production was found to be channeled to the microbial loop, making possible a bacterial growth exceeding primary production [Cho et al., 1994; Nielsen and Richardson, 1989] when the thermocline settling is delayed.

[50] In the center east side (area 4 (Figure 1b)), down to $80 \mathrm{~m}$ depth, average $T$ chl $a$ concentration was high (Figure 51), probably due to the frontal system of this area also suspected to correspond to the subduction zone $\left(40^{\circ}-42^{\circ} \mathrm{N}\right)$. A high value of integrated bacterial abundance (mostly LNA) was observed east of the Tchla central peak (Figures 6a, 6b, and 3a). Decoupling between bacteria and phytoplankton abundances in frontal areas were previously observed [Cho et al., 1994; Naganuma, 1997]. Average HNA1 and LNA abundances were not significantly different in the upper $100 \mathrm{~m}$ (Figure 5k), while LNA abundance was significantly higher than HNA1 abundance in deeper layers. Advective transfer of matter regarding the similar biogenic matter signature from the productive A1 (200 m depth traps) to the frontal area (400 m depth traps) were hypothesized by Mosseri et al. [2005] and Goutx et al. [2005]. In contrast with the other areas, the observed bacterial community corresponded to stations belonging to the $L N A>$ and $H N A 2>$ classes (Figure $8 \mathrm{~b}$ ). The related ecosystem was probably the one where a phytoplanktonic bloom was well pronounced. The unexpected low HNA1 concentrations could be explained by grazing pressure or shift 
between bacterial and phytoplanktonic blooms [Lochte et al., 1997; Ducklow, 1999].

[51] In the center west part (area 3 (Figure 1b)), Tchla values were low whereas high nitrate values were observed (Figures $3 \mathrm{a}$ and $3 \mathrm{~b}$ ). Bacterial integrated values were low in the core of $\mathrm{C} 4$ (st 56 (Figures 6a, 6b, and 3c)). HNA1 cells were more concentrated at the east side of $\mathrm{C} 4$ where high primary production was observed [Fernández et al., 2005b] while LNA cells were more concentrated at its west side (Figures $6 \mathrm{~b}$ and $6 \mathrm{a}$, respectively).

[52] In the southwest (area 5 (Figure 1b)), high bacteria concentrations were associated to a shallow MLD and undetectable nutrient levels in the surface waters, suggesting that the spring bloom in this area was almost over. Sedimentation of organic material in deep layers [Goutx et al., 2005] could explain the high concentrations of LNA observed between 200 and $400 \mathrm{~m}$ depth (Figure 9). High bacterial abundances at the surface layer could result from a higher organic matter availability occurring at the late stage of a phytoplankton bloom. The MLD, shallower than the ELD, may somehow isolate the microbial system and thus accelerate the phytoplankton bloom decline. Figure 4c provides evidence for the presence of nutrients in the euphotic layer, on the borders of A2 that does not reach the MLD: low ratios between the mixed and euphotic layers of integrated nitrate concentrations, situated well under the bisecting line. High HNA1 percentages in the surface layer suggest a weak impact of the grazing pressure in this area that corresponded to the most productive part of the POMME study area [Fernández et al., 2005b]. Sloppy feeding and phytoplanktonic exudation [Fuhrman, 1992] could counterbalance the effect of the potential bacterial predation by increasing the organic matter availability and sustaining a subsequent bacterial bloom [Ducklow, 1999].

[53] The southeast region (area 6 (Figure 1b)) was remarkably poor both in bacteria and Tchla. LNA were significantly more abundant than HNA1 down to $300 \mathrm{~m}$ depth at least, probably due to the poor nutrient content in this area suggesting that LNA dominance in this area could be accounted for by their adaptation to poor nutritional conditions [Zubkov et al., 2001]. Low HNA1 abundance could result from the low phytoplanktonic concentration (Figure 3a), i.e., low organic matter availability. This situation was also observed in the northern Gulf of Mexico, where low-DNA bacteria dominated in the euphotic layer [Jochem, 2001], and where bacteria concentrations where low $\left(2-4 \times 10^{5}\right.$ cells $\left.\mathrm{cm}^{-3}\right)$ [Jochem et al., 2004].

\subsection{Hydrodynamical Features and Bacterial Distribution}

\subsubsection{Study Area Subdivision}

[54] In the POMME study area, the evidence of the latitudinal phytoplankton bloom evolution was supported in particular by the observation of high level of $T \operatorname{chl} a$ in the south, low nutrient concentrations and shallow MLD, mainly around A2, whereas in the north, the bloom development was only potential, nutrients where not depleted and MLD was deeper. This north-south contrast could not be deduced from the bacterial distribution alone. Karrasch et al. [1996] stipulated that the north-south variation of the spring bloom in the North Atlantic is not always obvious, and that the different steps of the phytoplanktonic bloom are linked to mesoscale events. Hoppe et al. [2002, p. 171] reported that the "proximity of the heterotrophic and autotrophic patches in oligotrophic oceans suggest an unstable system reacting rapidly to changing environment conditions." These changes are due in particular to mesoscale dynamics that will increase phytoplankton patchiness [Martin, 2003]. The area was divided into nine regions (Figure 7) corresponding to a compromise between geostrophic currents and mesoscale features observed in the area (Figures 6a and $6 \mathrm{~b}$ ), each region being represented by a sufficient amount of samples.

\subsubsection{Mesoscale and Hydrodynamical Features:}

Impact on Bacterial Distribution

\subsubsection{Evidence of Physical Forcing on Bacteria Distribution}

[55] The strong northward jet delimitating A1 and C4 had a different influence on the bacterial distribution as compared to the southward jet, located between $\mathrm{C} 4$ and $\mathrm{A} 2$ (Figures $6 \mathrm{a}$ and $6 \mathrm{~b}$ ), and stirring nutrient-rich waters from the north. Conversely, the low LNA abundance between A1 and $\mathrm{C} 4$ corresponded to the northward jet between the two eddies and transporting warm surface waters $\left(13^{\circ} \mathrm{C}\right)$ from the southeast. The distribution of LNA integrated abundances appeared to be influenced by these currents, with (1) high abundances along the jet situated at the west border of $\mathrm{C} 4$, moving southward down to A2 east side, (2) low abundances along the jet flowing between $\mathrm{A} 1$ and $\mathrm{C} 4$ up to $43^{\circ} \mathrm{N}, 19.3^{\circ} \mathrm{W}$, and (3) higher concentrations in the southward jet along the east side of A1 (Figure 6a). The HNA1 distribution did not match the jet paths, and was more responding to trophic variations than the LNA distribution [Yanada et al., 2000], according to the relationships established in this study.

\subsubsection{Mesoscale Features and Bacterial Distribution}

[56] The MCA was carried out in order to quantify the impact on the bacterial distribution of mesoscale features such as the geostrophic currents. Results suggest that the eastern part of the cyclonic eddy C4 (CW1 (Figure 8)) and the frontal zone (FR (Figure 8)) were concentrating abnormally high abundances of HNA1 (HNA1> class stations (Table 5)) and HNA2 cells (HNA2> class stations (Table 5)), while phytoplankton was not particularly abundant according to Tchla values. The C4 cyclonic eddy was observed in the study area from winter to late summer [Le Cann et al., 2005; Fernández et al., 2005a] and Maixandeau [2004] observed high respiration rates in the core of $\mathrm{C} 4$ during spring that may be explained by the presence of high HNA1 concentrations. This eddy supplied continuously nitrate-rich waters to the mixed layer, with high regenerated production rates [Fernández et al., 2005a]. Frontal zones are known to involve vertical transport processes that supply nutrients from deeper waters and stimulate phytoplankton development [Sournia, 1992; Martin and Richards, 2001], which could account for the high HNA2 abundances in the FR region (Figures $3 \mathrm{c}$ and 7 ). Furthermore, turbulent conditions increase the recycling of dissolved organic matter, which could have enhanced the bacterial growth [Peters et al., 2002], until the establishment of the seasonal shallow thermocline.

[57] Conditions were quite different in the region of the A2 anticyclonic eddy. Its east side (A2E (Figure 8)) linked to the northward jet flowing between $\mathrm{C} 4$ and $\mathrm{A} 1$, was marked by very high bacterial abundances, mostly below 
$200 \mathrm{~m}$ depth $(A b d c 200 \mathrm{~m}>$ class (Table 5$))$. The geostrophic signature surrounding A2 was well followed by HNA1 and LNA bacterial subgroups (Figures $6 \mathrm{a}$ and $6 \mathrm{~b}$ ). The high abundances observed below $200 \mathrm{~m}$ depth, rather elevated for this area (Figure 9b), could be the sign of material exportation to deep waters as previously discussed. In contrast, the southeast area (SE (Figure 8)), was characterized by low bacterial abundances and no strong hydrodynamical features nor jets. Nevertheless, this low bacterial status seemed to follow the warm water tongue until $43^{\circ} \mathrm{N}$ between $\mathrm{A} 1$ and $\mathrm{C} 4$ (Figures $6 \mathrm{a}$ and $6 \mathrm{~b}$ ) as observed for nitrate concentrations and temperature [Fernández et al., 2005a]. This observation was well accounted for by the MCA. Indeed, stations belonging to $L N A>$ classes were along the jets flowing toward the southeast (SE), C4 east side (CW1) and northwest part (NW).

\section{Conclusion}

[58] The large data set collected during the POMME spring cruise enabled us to determine the spatial distribution in the upper $600 \mathrm{~m}$ of the study area of the three bacterial subpopulations (HNA1, HNA2 and LNA) resolved by flow cytometry.

[59] The vertical distribution of the three subpopulations was not identical. HNA2, when present, were restricted to the surface layer, suggesting that these bacteria could represent the facultative photoheterotrophic bacteria recently discovered by Kolber et al. [2000, 2001]. HNA1 were dominant in the upper $100 \mathrm{~m}$, and were spatially responding to high Tchla concentrations. This subpopulation seemed to be favored by the most labile DOC generated in the euphotic layer. HNA1 are certainly suited to high organic carbon releases in terms of size and abundance as observed by Jürgens et al. [2000]. Though also present in the upper layer, LNA were dominant below $100 \mathrm{~m}$, supporting the hypothesis of Zubkov et al. [2001], suggesting that they are adapted to nutrient limited waters. The LNA being more abundant in intermediate waters $(200-400 \mathrm{~m})$ their distribution was more affected by the hydrodynamic structures than HNA1. To account to some extent for the lack of synopticity of the data set inherent to the unavoidable long-lasting sampling, the study area was subdivided. This approach enabled to partially differentiate the nutritional from the hydrodynamical impact on the distribution of bacterial subpopulation.

[60] Acknowledgments. The authors wish to thank Gilles Reverdin and Laurent Mémery for their guidance and direction of the POMME project. We would like to thank the captain and crew of R/V L'Atalante for outstanding assistance during the POMME spring cruise. We also would like to thank Hervé Claustre for providing chlorophyll analyses and Laetitia Dugrais and Stuart Newman for cytometer sampling onboard. The POMME project is funded by PATOM and PROOF (CNRS/INSU).

\section{References}

Assenbaum, M., and G. Reverdin (2005), Near real-time analyses of the mesoscale circulation during the POMME experiment, Deep Sea Res., Part $I$, in press.

Banse, K. (1995), Zooplankton: Pivotal role in the control of ocean production, J. Mar. Sci., 52, 265-277.

Barbosa, A. B., H. M. Galvao, P. A. Mendes, X. A. Alvarez-Salgado, F. G Figueiras, and I. Joint (2001), Short-term variability of heterotrophic bacterioplankton during upwelling off the NW Iberian margin, Prog. Oceanogr., 51, 339-359.
Benzécri, J.-P. (1980), L’analyse des données, vol. 2, L’analyse des correspondances, Bordas, Paris.

Billen, G., P. Servais, and S. Becquevort (1990), Dynamics of bacterioplankton in oligotrophic and eutrophic aquatic environments: Bottom-up or top-down control?, Hydrobiologia, 2004, 37-42.

Buck, K. R., F. P. Chavez, and L. Campebell (1996), Basin-wide distributions of living carbon components and the inverted trophic pyramid of the central gyre of the North Atlantic Ocean, summer 1993, Aquat. Microbiol. Ecol., 10, 283-298.

Cho, B. C., and F. Azam (1988), Major role of bacteria in biogeochemical fluxes in the ocean's interior, Nature, 332, 441-443.

Cho, B. C., J.-K. Choi, and H. H. Hong (1994), Uncoupling of bacteria and phytoplankton during a spring diatom bloom in the mouth of the Yellow Sea, Mar. Ecol. Prog. Ser., 115, 181-190.

Claustre, H., et al. (2004), An inter-comparison of HPLC phytoplankton pigment methods using in situ samples: Application to remote sensing and database activities, Mar. Chem., 85, 41-61.

Cole, J. J., S. Findlay, and M. L. Pace (1988), Bacterial production in fresh and saltwater ecosystems: A cross-system overview, Mar. Ecol. Prog. Ser., 43, 1-10.

del Giorgio, P. A., J. M. Gasol, D. Vaqué, P. Mura, S. Agusti, and C. M. Duarte (1996), Bacterioplankton community structure: Protist control net production and the proportion of active bacteria in a coastal marine community, Limnol. Oceanogr., 41, 1169-1179.

de Mey, P., and Y. Ménard (1989), Synoptic analysis and dynamical adjustment of GOES 3 and Seasat altimeter eddy fields in the northwest Atlantic, J. Geophys. Res., 94, 6221-6231.

Ducklow, H. W. (1999), The bacterial component of the oceanic euphotic zone, FEMS Microbiol. Ecol., 30, 1-10.

Dufour, P., and J. P. Torreton (1996), Bottom-up and top-down control of the bacterioplankton from eutrophic to oligotrophic sites in the tropical northeastern Atlantic Ocean, Deep Sea Res., Part II, 48, 1305-1320.

Dutkiewicz, S., M. Follows, J. Marshall, and W. W. Gregg (2001), Interannual variability of phytoplankton abundances in the North Atlantic, Deep Sea Res., Part II, 48, 2323-2344.

Fernández, I. C., P. Raimbault, G. Caniaux, N. Garcia, and P. Rimmelin (2005a), Influence of mesoscale eddies on nitrate distribution during the POMME program in the north-east Atlantic Ocean, J. Mar. Syst., 55, $155-175$

Fernández, C. I., P. Raimbault, N. Garcia, P. Rimmelin, and G. Caniaux $(2005 \mathrm{~b})$, An estimation of annual new production and carbon fluxes in the northeast Atlantic Ocean during 2001, J. Geophys. Res., 110, C07S13, doi:10.1029/2004JC002616.

Frazel, D. W., and G. A. Berberian (1990), Distributions of chlorophyll and primary productivity in relation to water column structure in the eastern North Atlantic Ocean, Global Biogeochem. Cycles, 4, $241-$ 251.

Fuhrman, J. (1992), Bacterioplankton roles in cycling of organic matter: The microbial food web, in Primary Productivity and Biogeochemical Cycles in the Sea, edited by P. G. Falkowski and A. D. Woodhead, pp. 361-383, Springer, New York.

Fuhrman, J., T. D. Sleeter, C. A. Carlson, and L. M. Proctor (1989), Dominance of bacterial biomass in the Sargasso Sea and its ecological implications, Mar. Ecol. Prog. Ser., 57, 207-217.

Gasol, J. M., U. L. Zweifel, F. Peters, J. H. Fuhrman, and A. Hagstrom (1999), Significance of size and nucleic acid content heterogeneity as measured by flow cytometry in natural planktonic bacteria, Appl. Environ. Microbiol., 65, 4475-4483.

Gonzalès, N., R. Anadon, and L. Viesca (2003), Carbon flux through the microbial community in a temperate sea during summer: Role of bacterial metabolism, Aquat. Microbiol. Ecol., 33, 117-126.

Goutx, M., C. Guigue, N. Leblond, A. Desnues, A. Dufour, D. Aritio, and C. Guieu (2005), Particle flux in the northeast Atlantic Ocean during the POMME experiment (2001): Results from mass, carbon, nitrogen, and lipid biomarkers from the drifting sediment traps, J. Geophys. Res., doi:10.1029/2004JC002749, in press.

Grégori, G., A. Colosimo, and M. Denis (2001), Phytoplankton group dynamics in the bay of Marseilles during a 2-year survey based on analytical flow cytometry, Cytometry, 44, 247-256.

Grégori, G., M. Denis, D. Lefèvre, and J.-C. Romano (2003), Viabilité des bactéries hétérotrophes dans la baie de Marseille, C. R. Acad. Sci. Paris, 326, 739-750.

Greenacre, M. J. (1984), Theory and Applications of Correspondence Analysis, Elsevier, New York.

Guieu, C., M. Roy-Barman, N. Leblond, C. Jeandel, M. Souhaut, B. Le Cann, A. Dufour, and C. Bournot (2005), Vertical particle flux in the northeast Atlantic Ocean (POMME experiment), J. Geophys. Res., doi:10.1029/2004JC002672, in press.

Häder, D.-P., H. D. Kumar, R. C. Smith, and R. C. Worrest (1998), Effects on aquatic systems, J. Photochem. Photobiol. B, 46, 53-68. 
Hoppe, H. G., K. Gocke, R. Koppe, and C. Begler (2002), Bacterial growth and primary production along a north-south transect of the Atlantic Ocean, Nature, 416, 168-171.

Ihaka, R., and R. Gentleman (1996), R: A language for data analysis and graphics, J. Comput. Graph. Stat., 5, 299-314.

Jenkins, W. J. (1988), Nitrate flux into the euphotic zone near Bermuda, Nature, 331, 521-523.

Jochem, F. J. (2001), Morphology and DNA content of bacterioplankton in the northern Gulf of Mexico: Analysis by epifluorescence microscopy and flow cytometry, Aquat. Microbiol. Ecol., 25, 179-194.

Jochem, F. J., P. J. Lavrentyev, and M. R. First (2004), Growth and grazing rates of bacteria groups with different apparent DNA content in the Gulf of Mexico, Mar. Biol., 145, 1213-1225.

Jürgens, K., J. M. Gasol, and D. Vaqué (2000), Bacteria-flagellate coupling in microcosm experiments in the central Atlantic Ocean, J. Explor. Mar Biol. Ecol., 245, 127-147.

Karrasch, B., H. G. Hoppe, and S. Podewski (1996), The role of mesoscale hydrography on microbial dynamics in the northeast Atlantic: Results of a spring bloom experiment, J. Mar. Res., 54, 99-122.

Kirchman, D. L., and P. A. Wheeler (1998), Uptake of ammonium and nitrate by heterotrophic bacteria and phytoplankton in the sub-Arctic Pacific, Deep Sea Res., Part I, 45, 347-365.

Kolber, Z. S., C. L. Van Dover, R. A. Niederman, and P. G. Falkowski (2000), Bacterial photosynthesis in surface waters of the open ocean, Nature, 407, 117-179.

Kolber, Z. S., F. G. Plumley, A. S. Lang, J. T. Beatty, R. E. Blankenship, C. L. Van Dover, C. Vetriani, M. Koblizek, C. Rathgeber, and P. G. Falkowski (2001), Contribution of aerobic photoheterotrophic bacteria to the carbon cycle in the ocean, Science, 292, 2492-2495.

Kuipers, B., G. J. van Noort, J. Vosjan, and G. J. Herndl (2000), Diel periodicity of bacterioplankton in the euphotic zone of the subtropical Atlantic Ocean, Mar. Ecol. Prog. Ser., 201, 13-25.

Lebaron, P., P. Servais, H. Agogué, C. Courties, and F. Joux (2001), Does the nucleic acid content of individual bacteria cells allows us to discriminate between active and inactive cells in aquatic systems?, Appl. Environ. Microbiol., 67, 1775-1782.

Leblanc, K., A. Leynaert, I. C. Fernandez, P. Rimmelin, T. Moutin P. Raimbault, J. Ras, and B. Quéguiner (2005), A seasonal study of diatom dynamics in the North Atlantic during the POMME experiment (2001): Evidence for Si limitation of the spring bloom, J. Geophys. Res., 110, C07S14, doi:10.1029/2004JC002621.

Le Cann, B., M. Assenbaum, J.-C. Gascard, and G. Reverdin (2005), Observed mean and mesoscale upper ocean circulation in the midlatitude northeast Atlantic, J. Geophys. Res., 110, C07S05, doi:10.1029/ 2004JC002768

Levitus, S., and T. P. Boyer (1994), World Ocean Atlas 1994, vol. 4 Temperature, NOAA Atlas NESDIS 4, 129 pp., Natl. Oceanic and Atmos. Admin., Silver Spring, Md.

Levitus, S., R. Burgett, and T. P. Boyer (1994), World Ocean Atlas 1994 vol. 3, Salinity, NOAA Atlas NESDIS 3, 111 pp., Natl. Oceanic and Atmos. Admin., Silver Spring, Md.

Li, W. K. W., and W. G. Harrison (2001), Chlorophyll, bacteria and picophytoplankton in ecological provinces of the North Atlantic, Deep Sea Res., Part II, 48, 2271-2293.

Li, W. K. W., J. F. Jellett, and P. M. Dickie (1995), DNA distributions in planktonic bacteria stained with TOTO or TO-PRO, Limnol. Oceanogr. $40,1485-1495$

Li, W. K. W., E. J. H. Head, and W. G. Harrison (2004), Macroecological limits of heterotrophic bacterial abundance in the ocean, Deep Sea Res. Part I, 51, 1529-1540.

Lochte, K., P. K. Bjornsen, H. Giesenhagen, and A. Weber (1997), Bacteria standing stock and production and their relation to phytoplankton in the Southern Ocean, Deep Sea Res., Part II, 44, 321-340.

Long, R. A., and F. Azam (2001), Microscale patchiness of bacterioplankton assemblage richness in seawater, Aquat. Microbiol. Ecol., 26, $103-$ 113

Maixandeau, A. (2004), La pompe biologique: Fonctionnement de la communauté microbienne et relation avec le contexte hydrodynamique, $\mathrm{Ph}$.D. thesis, Univ, de la Mediterranée, Marseille, France.

Martin, A. P. (2003), Phytoplankton patchiness: The role of lateral stirring and mixing, Prog. Oceanogr., 57, 125-174.

Martin, A. P., and K. J. Richards (2001), Mechanisms for vertical nutrient transport within a North Atlantic mesoscale eddy, Deep Sea Res., Part II, $48,757-773$

Martin, A. P., K. J. Richards, and M. J. R. Fasham (2001), Phytoplankton production and community structure in an unstable frontal region, J. Mar Syst., 28, 65-89.
McGillicuddy, D. J., Jr., and A. R. Robinson (1997), Eddy-induced nutrient supply and new production in the Sargasso Sea, Deep Sea Res., Part I, 44, $1427-1450$

Mémery, L., G. Reverdin, J. Paillet, and A. Oschlies (2005), Introduction to the POMME special section: Thermocline ventilation and biogeochemical tracer distribution in the northeast Atlantic Ocean and impact of mesoscale dynamics, J. Geophys. Res., doi:10.1029/2005JC002976, in press.

Morel, A., and J. F. Berthon (1989), Surface pigments, algal biomass profiles, and potential production of the euphotic layer: Relationships reinvestigated in view of remote-sensing applications, Limnol. Oceanogr., 34, $1545-1562$

Morel, A., and S. Maritorena (2001), Bio-optical properties of oceanic waters: A reappraisal, J. Geophys. Res., 106, 7163-7180.

Mosseri, J., B. Quéguiner, P. Rimmelin, N. Leblond, and C. Guieu (2005), Silica fluxes in the northeast Atlantic frontal zone of Mode Water formation $\left(38^{\circ}-45^{\circ} \mathrm{N}, 16^{\circ}-22^{\circ} \mathrm{W}\right)$ in $2001-2002, J$. Geophys. Res. 110, C07S19, doi:10.1029/2004JC002615.

Naganuma, T. (1997), Abundance and production of bacterioplankton along a transect of Ise Bay, Japan, J. Oceanogr., 53, 579-583.

Nielsen, T. G., and K. Richardson (1989), Food chain structure of the North Sea plankton communities: Seasonal variations of the role of the microbial loop, Mar. Ecol. Prog. Ser, 56, 75-87.

Peters, F., C. Marassé, H. Havskum, F. Rassoulzadegan, J. R. Dolan, M. Alcarez, and J. M. Gasol (2002), Turbulence and the microbial food web: Effects on bacterial losses to predation and on community structure, J. Plankton Res., 24, 321-331.

Siegel, D. A., R. Iturriaga, R. R. Bidigare, H. Pak, R. C. Smith, T. D. Dickey, J. Marra, and K. S. Baker (1990), Meridional variations of the springtime phytoplankton community in the Sargasso Sea, J. Mar. Res., $48,379-412$

Siegel, D. A., S. C. Doney, and J. A. Yoder (2002), The North Atlantic spring phytoplankton bloom and Sverdrup's Critical Depth hypothesis, Science, 296, 730-733.

Sieracki, M. E., E. M. Haugen, and T. L. Cucci (1995), Overestimation of heterotrophic bacteria in the Sargasso Sea: Direct evidence by flow and imaging cytometry, Deep Sea Res., Part I, 42, 1399-1409.

Simon, M., B. C. Cho, and F. Azam (1992), Significance of bacterial biomass in lakes and the ocean: Comparison to phytoplankton biomass and biogeochemical implications, Mar. Ecol. Prog. Ser., 86, 103-110.

Sournia, A. (1992), Frontal studies in France-JGOFS: A four year summary, Ann. Inst. Oceanogr., 69, 47-55.

Stramma, L. (1984), Geostrophic transport in the warm water sphere of the eastern subtropical North Atlantic, J. Mar. Res., 42, 537-558.

Sverdrup, H. U. (1953), On conditions for the vernal blooming of phytoplankton, J. Conseil Int. Explor. Mer, 18, 287-295.

Tréguer, P., and P. Le Corre (1975), Manuel d'analyses des sels nutritifs dans l'eau de mer (Utilisation de l'Autoanalyser II), 2nd ed., report, 110 pp., Lab. de Chim. Mar. Univ. é de Bretagne Occident., Brest, France.

Troussellier, M., C. Courties, P. Lebaron, and P. Servais (1999), Flow cytometric discrimination of bacterial populations in seawater based on SYTO 13 staining of nucleic acids, FEMS Microbiol. Ecol., 29, 319330

Wheeler, P. A., and D. L. Kirchman (1998), Utilization of inorganic and organic nitrogen by bacteria in marine systems, Limnol. Oceanogr., 31, 998-1009.

Yanada, M., T. Yokokawa, C. W. Lee, and H. Tanaka (2000), Seasonal variation of two different heterotrophic bacterial assemblages in subarctic coastal seawater, Mar. Ecol. Prog. Ser., 204, 289-292.

Zubkov, M. V., B. M. Fuchs, P. H. Burkill, and R. Amann (2001), Comparison of cellular and biomass specific activities of dominant bacterioplankton groups in stratified waters of the Celtic Sea, Appl. Environ. Microbiol., 67, 5210-5218.

G. Caniaux, Centre National de Recherche Météorologique, 42 Avenue G. Coriolis, F-31057 Toulouse Cedex, France. (guy.caniaux@meteo.fr)

M. Denis, D. Lefèvre, and M. Thyssen, Centre d'Océanologie de Marseille, Laboratoire de Microbiologie, Géochimie et Ecologie Marines, Centre National de la Recherche Scientifique, UMR 6117, Université de la Méditerranée, 163 avenue de Luminy, Case 901, F-13288 Marseille Cedex 09, France. (denis@com.univ-mrs.fr; lefevre@com.univ-mrs.fr; thyssen@ com.univ-mrs.fr)

C. I. Fernández, Centre d'Océanologie de Marseille, Laboratoire d'Océanographie et de Biogéochimie, Campus de Luminy, F-13288 Marseille Cedex 09, France. (fernandez@com.univ-mrs.fr)

J. Ras, Laboratoire d'Océanographie de Villefranche, B.P. 28, F-06234 Villefranche-sur-Mer Cedex, France. (josephine.ras@obs-vlfr.fr) 
\begin{tabular}{c} 
N1 \\
1 \\
$\frac{1}{0}$ \\
\hline 0
\end{tabular}

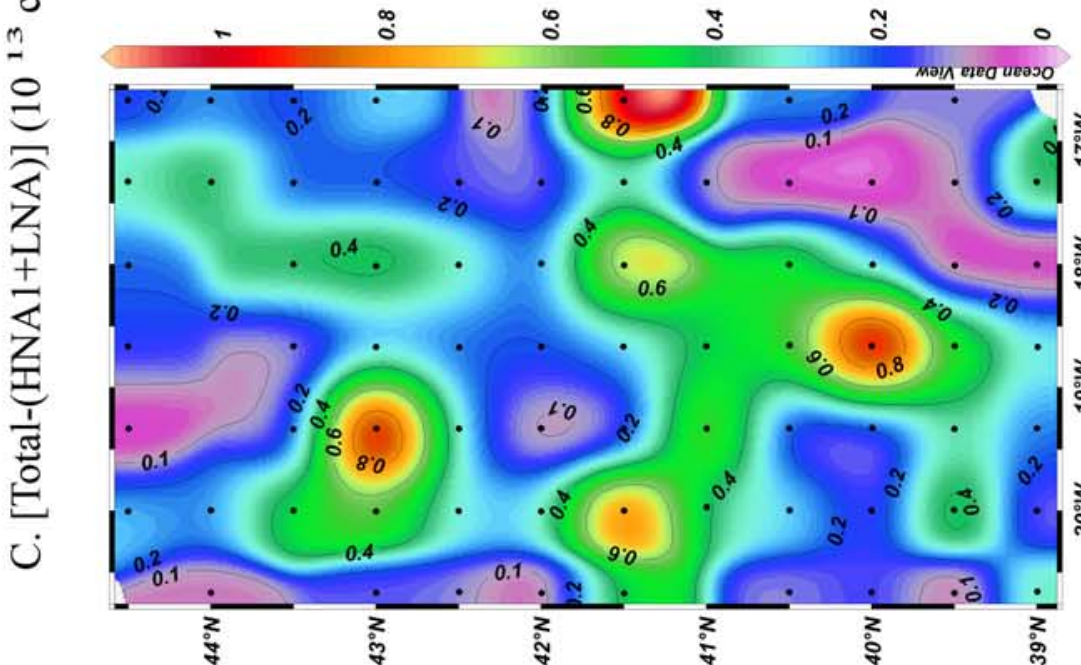

뀹

寻

อ

กิ

$\sigma \frac{\pi}{0}$

元文

잉

(
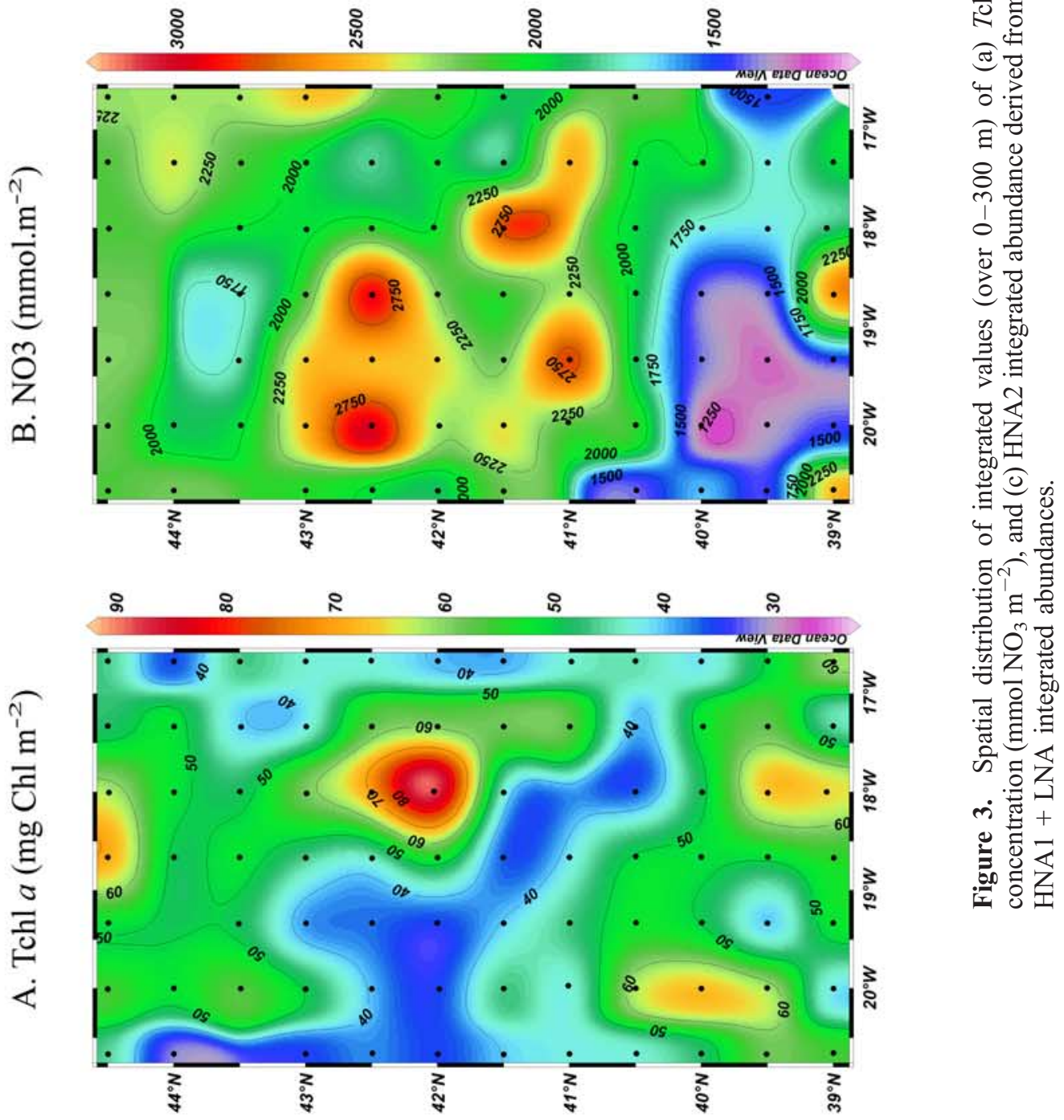
A)

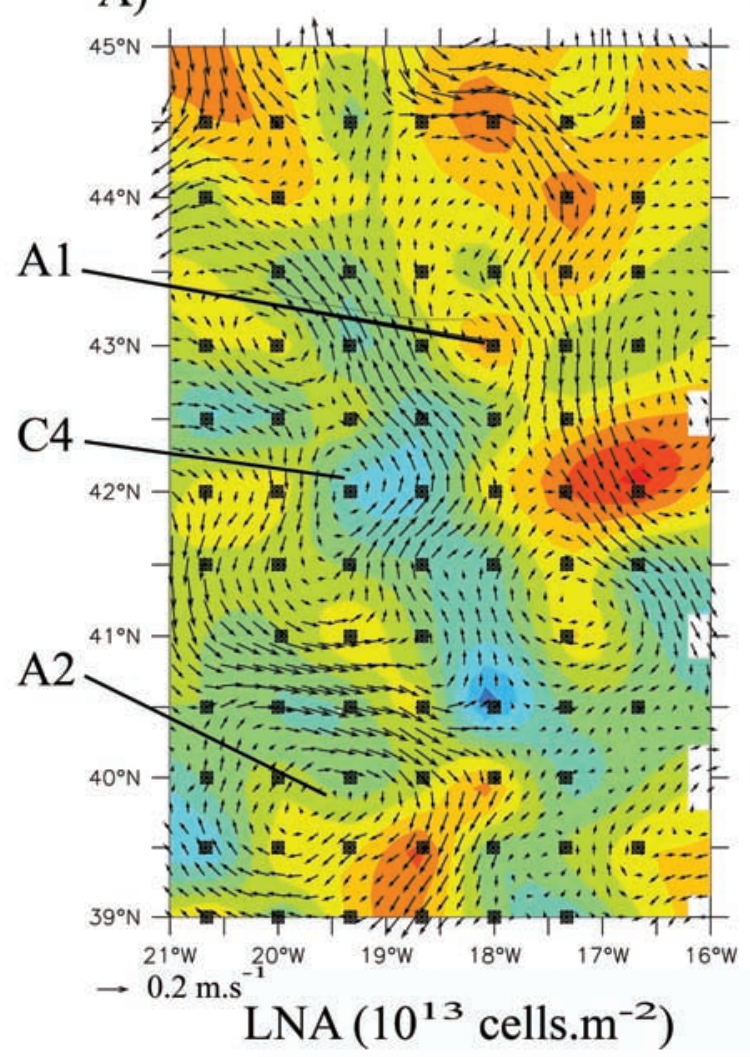

B)

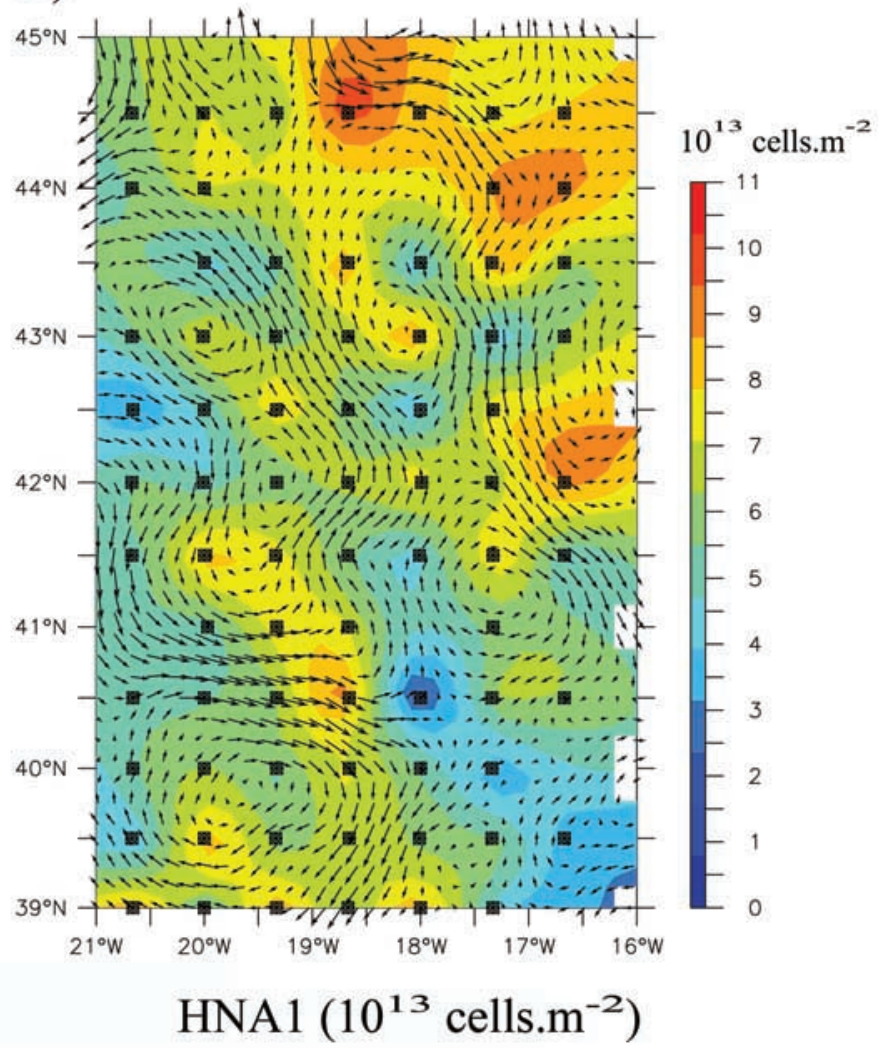

Figure 6. Upper layer geostrophic current field superimposed on the bacteria abundances integrated between 0 and $300 \mathrm{~m}$ depth. (a) LNA integrated values $\left(10^{13}\right.$ cells $\left.\mathrm{m}^{-2}\right)$. (b) HNA1 integrated values $\left(10^{13}\right.$ cells $\left.^{-2}\right)$. Labeled mesoscale features: $\mathrm{A} 1$ and $\mathrm{A} 2$, anticyclonic gyre; $\mathrm{C} 4$, cyclonic gyre. 